\author{
UNIVERSIDADE DE SÃO PAULO \\ FACULDADE DE ODONTOLOGIA DE BAURU
}

EVEN AKEMI TAIRA

Changes in the proteomic profile of acquired enamel pellicles formed in vivo for different times, after exposure to hydrochloric acid

Alterações no perfil proteômico da película adquirida formada in vivo e em diferentes tempos, após exposição ao ácido

Clorídrico

BAURU 



\title{
Changes in the proteomic profile of acquired enamel pellicles formed in vivo for different times, after exposure to hydrochloric acid.
}

\section{Alterações no perfil proteômico da película adquirida formada in vivo e em diferentes tempos, após exposição ao ácido \\ Clorídrico}

\begin{abstract}
Dissertation presented to the Bauru School of Dentistry of the University of São Paulo to obtain the degree of Master in Science in the Applied Dental Science Program, Stomatology and Oral Biology concentration area.

Supervisor: Prof. Dra Marília Afonso Rabelo Buzalaf

Dissertação apresentada à Faculdade de Odontologia de Bauru da Universidade de São Paulo para obtenção do título de Mestre em Ciências no Programa de Ciências Odontológicas Aplicadas, área de concentração Estomatologia e Biologia Oral.

Orientadora: Prof. Dr ${ }^{a}$ Marília Afonso Rabelo Buzalaf
\end{abstract}

Versão Corrigida

BAURU 


\section{Taira, Even Akemi}

T137c Changes in the proteomic profile of acquired enamel pellicles formed in vivo for different times, after exposure to hydrochloric acid / Even Akemi Taira Bauru, 2017.

78 p. : il. ; $31 \mathrm{~cm}$.

Dissertação (Mestrado) - Faculdade de Odontologia de Bauru. Universidade de São Paulo

Orientadora: Prof. Dra Marília Afonso Rabelo Buzalaf

Nota: A versão original desta dissertação encontra-se disponível no Serviço de Biblioteca e Documentação da Faculdade de Odontologia de Bauru - FOB/USP.

Autorizo exclusivamente para fins acadêmicos e científicos, a reprodução total ou parcial desta dissertação/tese, por processos fotocopiadores e outros meios eletrônicos.

Assinatura:

Data:

Comitê de Ética da FOB-USP

Protocolo n : 44737115.4 .0000 .5417

Data: $19 / 08 / 2015$ 
FOLHA DE APROVAÇÃO 



\section{DEDICATÓRIA}

Aos meus pais Yoshinobu e Cecília,

Que sempre acreditaram em mim, espero que em forma de realizações e sucesso, eu possa recompensá-los.

Aos meus irmãos Ryan e Juliane,

Pelo companheirismo, por crescerem, rirem e chorarem comigo.

Aos meus avós, prímos, tíos e tías e as grandes amizades que fiz ao longo da vida.

$\mathcal{A}$ todo o apoío, força, abraços e incentivo. Aos momentos juntos, que para mím são as coísas maís preciosas do mundo. 



\section{AGRADECIMENTOS}

\section{À Deus,}

Obrigada, pela minha familia, aos amigos que encontrei pelo caminho, pelas oportunidades, por ter colocado em minha vida pessoas tão boas.

\section{Aos meus pais Yoshinobu e Cecília.}

É com muita dificuldade, que eu tento pôr em palavras, o sentimento que tenho por vocês, é tanta gratidão e amor que é impossível escrever em algumas páginas. A luta que vocês realizaram, para que eu possa ter a melhor educação possível, e como vocês deixaram muitas das suas vontades e sonhos, para que os meus fossem realizados. A confiança que sempre depositaram em mim, e em todas as minhas decisões. A todo o apoio, pois eu sei que, não importando o que aconteça, eu posso sempre ter vocês ao meu lado. A todos os ensinamentos e momentos juntos. Agradeço tanto a Deus por ter me dado vocês como meus pais, e rezo sempre para que eu consiga retribuir tudo o que me foi dado, e que no futuro, eu possa passar aos meus filhos todo o amor e carinho do mundo, como vocês fizeram. Ao amor que me deram, que é o que eu tenho de mais valioso no coração, obrigada, amo incondicionalmente vocês.

\section{Aos meus irmãos Ryan e Juliane.}

Vocês fizeram a minha vida ser muito mais divertida. Agradeço a Deus por ter me dado meus dois melhores amigos e companheiros de vida. Uma infância com lembranças tão boas, onde vocês estão em todas elas. Nos momentos ruins, também estavam ao meu lado, me ajudando. Eu espero que possamos ter muitos mais anos de convivência, brincando, rindo, chorando e brigando. Obrigada por estarem comigo, meus melhores amigos da vida, amo vocês com todo o coração.

\section{Aos meus avós paternos (in memoriam) Yosio e Anita.}

Obrigada por estarem comigo, e no meu caminho. Eu sei que sempre estarão torcendo e zelando por mim, aonde quer que estejam. Gostaria de ter aproveitado melhor cada segundo com vocês, mas sei que a saudades que sinto, existe, pois tivemos momentos muito bons juntos. Levo vocês com muito amor no coração. 



\section{Aos meus avós maternos, Kiyoshi e Kazuko.}

Quando meus pais não puderam estar comigo, vocês foram os meus pais, e eu sou muito agradecida. Agradeço pela torcida, para que eu consiga ser uma boa pessoa, obrigada por serem um exemplo para mim. Por terem me ensinado que a família é o bem mais valioso que temos.

\section{Aos meus tios, tias e primos.}

Obrigada a todos vocês por tantos momentos felizes juntos, por torcerem tanto por mim, meus tios e tias foram meus pais quando precisei, meus primos foram meus irmãos. São parte do que eu tenho de mais importante na vida. Obrigada, espero estarmos sempre juntos.

As minhas amigas da faculdade, Ana Priscila Gomes, Daiana Moreli, Jéssica Colavite, Mariana Gentil e Patricia Maximo.

Vocês fizeram parte da minha vida em um momento tão importante, que é a faculdade. Viraram uma espécie de família, já que passávamos tanto tempo juntas estudando, aprendendo, trabalhando, contando nossos problemas, rindo e apoiando umas às outras. Agora há a distância, mas a amizade é algo muito forte, mais que qualquer distância. Torço muito por vocês, obrigada por tudo.

\section{A minha amiga Tatiana Martini.}

Amiga, em dois anos de mestrado, nasceu uma amizade tão grande. Agradeço por você estar presente nestes 2 últimos anos da minha vida. Rimos tanto, e choramos tanto neste pouco tempo de amizade, mas eu já sei que posso contar com você pra toda a minha vida. Assim espero que você conte comigo também. Te admiro muito, e uso você como exemplo de pessoa forte. Obrigada, por ser alguém tão iluminada e partilhar sua luz comigo.

\section{A minha amiga Talita Ventura.}

"Talita adquirida", admiro tanto você, uma pessoa de tão bom coração, que sempre quando eu precisava de ajuda, pude contar com você, com a sua amizade e apoio. Obrigada por sempre, me ajudar nesta pesquisa, sem você eu não teria conseguido. Eu acredito que quando ajudamos as pessoas, cria-se uma energia boa, 

e que está, sempre volta um dia. Por isso acredito no seu imenso sucesso. Pois você está sempre disposta a ajudar. Obrigada por tudo, e que Deus sempre te ilumine muito.

A minha amiga de pesquisa e orientadora de Iniciação Científica Cintia.

A você tenho muito a agradecer, pois foi você que me proporcionou o meu primeiro contato com laboratório e pesquisa. Agradeço a oportunidade de ser aluna de iniciação científica, por ter me acolhido tão bem, por ter toda a paciência de me explicar tantas coisas, por ter me passado tanto conhecimento, conselhos de vida, e por sua amizade. Obrigada por me orientar desde que eu era apenas uma IC, e depois no mestrado, sempre quando eu precisei, você se dispôs a me ajudar, com muito carinho. Eu agradeço de coração todo o seu empenho neste trabalho.

\section{A minha amiga Luiza Cassiano.}

Lu, agradeço muito a você. Por todos os momentos juntos nas coletas, por toda a sua ajuda, com o artigo, com pôster, com congresso, com o proteoma, com as tabelas entre outras coisas. Mas principalmente por todos os conselhos e conversas, por sempre estar disposta a me ajudar, pelos momentos de risada. Obrigada.

\section{Aos meus amigos Vinicius e Aline Braga.}

Juntos com a Tati, formamos um quarteto. Começar no mestrado, foi como começar na escola, sem conhecer quase ninguém, com o medo do início. Mas com vocês a amizade foi rápida e fácil. Obrigada por tantos momentos de risadas juntos, e tantos momentos de agonia, que passamos, mas sempre tendo o apoio do outro. A amizade de vocês e os momentos que tivemos juntos, eu levarei no meu coração.

\section{Aos meus queridos colegas e amigos do Laboratório de Bioquímica,}

Acho que eu tive muita sorte, de ter vocês no meu caminho. Pessoas que me acolheram, e me fizeram sentir muito bem neste laboratório. Obrigada pela a ajuda de cada um, por terem deixado tudo o que era muito pesado e difícil, mais leve e fácil. Por todos os momentos no laboratório, na cozinha, nas aulas, e nas nossas festinhas. Sou muito grata por ter vocês em minha vida. 

Ás técnicas e especialistas do Laboratório de Bioquímica, Larissa, Thelma e Aline,

Obrigada por todo o ensinamento, a paciência e por sempre estraem dispostas a ajudar, meus agradecimentos.

Aos professores da Disciplina de Bioquímica, Professor Dr. Rodrigo Cardoso de Oliveira e Professora Dra. Ana Carolina Magalhães,

Obrigada por serem pacientes, e sempre terem essa vontade de nos passar conhecimento, levo cada orientação de vocês para sempre comigo. Obrigada

\section{A secretária do Departamento Dalva Ribeiro de Oliveira.}

Obrigada Dalva, por sempre nos atender com muito carinho. Sempre com muita paciência. Por todas as dúvidas. Obrigada.

Aos voluntários desta pesquisa,

A todos os meus voluntários, que fizeram tanto esforço para me ajudar neste trabalho. Obrigada por terem aceitado a participar desta pesquisa. Acredito que sempre que fazemos algo de bom, um dia isso retornará, e espero que muitas coisas boas retornem a vocês.

\section{Ao Professor Dr. Carlos Ferreira dos Santos,}

Por abrir as portar da clínica do laboratório de farmacologia para que as coletas fossem realizadas. Agradeço a todos do laboratório de farmacologia pela atenção e ajuda.

À Faculdade de Odontologia de Bauru- FOB/USP, na pessoa da diretora Prof. ${ }^{a}$ Dr $^{a}$ Maria Aparecida Moreira Machado,

É um honra poder realizar a pós-graduação em nível de Mestrado nesta importantíssima instituição, no qual me deu todo o suporte possível para realização deste sonho. Obrigada FOB-USP por permitir está realização.

À Coordenação de Aperfeiçoamento de Pessoal de Nível Superior (CAPES), pela concessão da minha bolsa de Mestrado, que foi crucial e de extrema importância para meu aprimoramento profissional e pessoal. 

"A felicidade não está na estrada que leva a algum lugar. A felicidade é a própría estrada." Bob Dylan 



\section{AGRADECIMENTOS ESPECIAIS}

Agradeço à minha orientadora Prof ${ }^{a}$ Dra $^{\mathrm{a}}$ Marília Afonso Rabelo Buzalaf,

Agradeço muito a Deus por me ter colocado a oportunidade de trabalhar com a senhora. Desde quando eu era uma aluna de iniciação científica, sempre fui muito bem acolhida e muito bem recebida pela professora. E depois quando decidi voltar $\mathrm{e}$ tentar o mestrado, novamente fui muito bem tratada com toda a sua paciência em me explicar como seria este estudo com película, com toda a sua gentileza, e toda a sua experiência.

Agradeço a sua imensa confiança, pois sendo sua orientada, eu sentia o quanto a senhora coloca fé nas nossa pesquisas, o quanto a senhora confia em seus alunos e nunca duvidou da nossa competência. Este incentivo para mim como sua aluna, contou muito.

Obrigada por todos os seus ensinamentos, que foram muitos, e por sempre estar disposta a me atender sempre que foi preciso, pelos e-mails respondidos, seja qual for a hora, mesmo sendo tão ocupada, a professora foi uma orientadora muito presente.

E finalmente, agradeço o que eu considero de mais importante, que foi o seu carinho. Por ser uma pessoa que torce muito pelos seus alunos, e que deseja que eles sempre voem mais alto possível. Por todo o incentivo, por cada torcida para que tudo desse certo. É uma grande honra ter trabalhado com uma pessoa tão admirável, não só apenas por seus trabalhos e prêmios, mas por ser uma pessoa tão iluminada e tão gentil. A sua gentileza e amor pela profissão, é algo que tento me espelhar sempre.

Obrigada por esta caminhada juntas professora, lembrarei sempre com muito carinho. Que Deus possa cuidar sempre desta luz que a senhora carrega no coração. 

"Você tem que ser o espetho da mudança que está propondo. Se eu quero mudar o mundo, tenho que começar por mim." Mahatma Gandhi 



\section{ABSTRACT \\ Changes in the proteomic profile of acquired enamel pellicles formed in vivo for different times, after exposure to hydrochloric acid}

Saliva it is an important factor against enamel and dentin damages. When the saliva enter in contact with the dental surface, results in a selective adsorption of salivary proteins, glycoproteins and lipids. This adsorption formed an organic free-bacterial film, which when formed in the enamel, is denominated acquired enamel pellicle. The presence of this proteins covering the enamel tissues, has the function of lubrication, buffering and remineralization capabilities, making it an important factor against dental erosion. The objective of this study was detected changes in the protein profile of acquired enamel pellicles (AEP) formed in vivo for different times, after application of hydrochloric acid $(\mathrm{HCl})$. The experimental was realized in 12 consecutive days. On each day, nine subjects, (aged 18 to 35 years, non-smokers, with good general and oral health) were submitted to dental prophylaxis with pumice. After 3 or 120 min, time of formation of the acquired pellicle, the teeth were isolated with cotton rolls and, submitted for a 3 different procedures, one procedure of each day, $50 \mu \mathrm{L}$ of $0.1 \mathrm{M} \mathrm{HCl}$ $(\mathrm{pH}=1.0), 0.01 \mathrm{M} \mathrm{HCl}(\mathrm{pH}=2.0)$ or deionized water were applied on the buccal surface of the teeth for $10 \mathrm{~s}$. The application of $\mathrm{HCl}$ was in all teethes from the superior and lower arch, in vestibular surface. In sequence the AEP was collected using an electrode filter paper pre-soaked in 3\% citric acid. This procedures was repeted for one more day. After protein extraction, the samples were submitted to reverse phase liquid chromatography coupled to mass spectrometry (nLC-ESI-MS/MS). Label-free quantification was performed (Protein Lynx Global Service software). A total of 180 proteins were successfully identified in the AEP samples. The number of identified proteins increased with the time of pellicle formation. Only 4 proteins were present in all the groups (isoforms of IgA, Serum albumin and Statherin). The greatest number of proteins identified uniquely in one of the groups was obtained for the groups treated with $\mathrm{HCl}$ after $2 \mathrm{~h}$ of pellicle formation ( 50 proteins). Conclusion: Proteins resistant to removal by $\mathrm{HCl}$, such as Serum Albumin and Statherin, were identified even in the 

short-term AEP. In addition, 120-min pellicle present many proteins that are resistant to removal by $\mathrm{HCl}$. This suggests an increase in the protection against intrinsic acids along the time of pellicle formation, which should be evaluated in future studies.

Keywords: Acquired Pellicle; enamel; dental erosion; gastroesophageal reflux; proteomics. 



\section{RESUMO}

A saliva é um importante meio de proteção contra danos ao esmalte e dentina, e é quando ela entra em contato com a superfície dentária, que ocorre uma adsorção seletiva de proteínas salivares, glicoproteínas e lipídeos. Esta adsorção forma um filme orgânico, que é isenta de bactérias, que quando formada sobre esmalte dentário é denominada de película adquirida do esmalte (PAE). A presença destas proteínas recobrindo os tecidos dentários auxilia na lubrificação, tem capacidades de tamponamento e de remineralização, tornando-se um importante fator de proteção contra erosão dentária. O objetivo deste trabalho foi detectar as alterações no perfil protéico na película adquirida do esmalte (PAE) formada in vivo, após a exposição ao ácido clorídrico. Os experimentos foram realizados em 12 dias consecutivos. Em cada dia, os voluntários ( $n=9)$, com idade entre 18 a 35 anos, não fumantes, e com um bom estado de saúde geral e bucal, eram submetidos a uma profilaxia dentária com pedra pomes. Depois de 3 min ou 120 min e após a formação PAE, os dentes eram isolados com rolos de algodão e submetidos a 3 procedimentos distintos, sendo um deles realizado a cada dia: aplicação de $50 \mu \mathrm{L}$ de ácido clorídrico $(0,1 \mathrm{M}, \mathrm{pH} 1)$, ácido clorídrico $(0,01 \mathrm{M}, \mathrm{pH} 2)$ ou água deionizada por 10 segundos. A aplicação foi feita, em todos os dentes dos arcos superiores e inferiores na face vestibular. $\mathrm{Na}$ sequência, a película foi removida com um papel de filtro umedecido em ácido cítrico a $3 \%$. Este procedimento foi repetido por mais uma vez e foi feito um "pool' com os papeis de filtro obtidos dos 9 voluntários, para cada procedimento e tempo de formação (Água-3min, Água-2h, pH2-3min, pH2-2h, pH1-3min e pH1-2h). Após extração das proteínas, as mesmas foram submetidas à cromatografia líquida de fase reversa interligada a um espectrômetro de massas (nLC-ESI-MS/MS). Quantificação proteômica livre de marcadores foi feita utilizando o software (Protein Lynx Global Service software). Um total de 180 proteínas foram encontradas nas amostras de PAE. E o número de proteínas identificadas crescia conforme aumentou-se o seu tempo de formação da película. Somente 4 proteínas foram presentes em todos os grupos sendo estas isoforms de $\lg A$, Serum albumin e Statherin. Um grande número proteínas foram identificadas como sendo únicas dos grupos tratados com $\mathrm{HCl}$, depois de $2 \mathrm{~h}$ de formação de película ( 50 proteínas). Em conclusão as proteínas são 

resistentes a remoção por $\mathrm{HCl}$, e tanto que Serum Albumin e Statherin, foram identificadas em películas formadas em tempos precoces. Para películas formadas no tempo de 120-min foram encontradas muitas proteínas que são resistentes a remoção por $\mathrm{HCl}$. Este fato sugere um aumento da proteção contra ácidos intrínsecos conforme o tempo de formação de película, o que deverá ser avaliada em estudos futuros.

Palavras-chave:. Película Adquirida. Esmalte Dentário. Erosão Dental. Refluxo Gastroesofágico. Proteômica. 



\section{TABLE OF CONTENTS}

1 INTRODUCTION

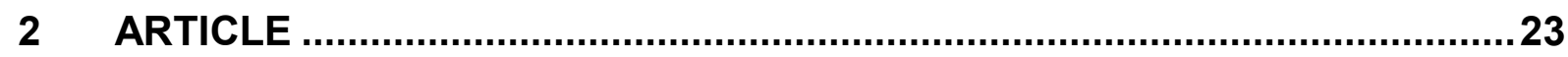

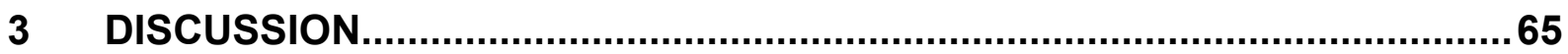

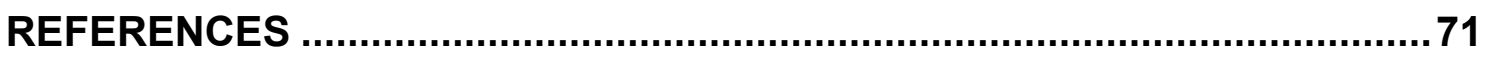

ANNEX 





\section{INTRODUCTION}

In the last decades, it has been observed that the dental losses, are being studied extensively, especially those caused by non-bacterial acids. Dental erosion is one of the most documented lesion with more studies in the last few years. This lesion it is a multifactorial condition caused by a complex interaction the patient and the nutritional factors, and also influenced by other factors such as education, behavior, occupation, level of knowledge, and health. In the first instance, there is a softening of the tooth surface and this process is followed by a dissolution of the enamel crystals layer-by-layer, leading to permanent volume tooth loss with a remaining softened surface (LUSSI et al., 2011).

The dental erosion could be classified, taking into account their etiology, could be extrinsic or intrinsic (MAGALHAES et al., 2009). The intrinsic erosion is the consequence of the action of endogenous acids, originating from gastric reflux, chronic regurgitation, alcoholism, pregnancy, or disorders of the nervous system, such as anorexia and / or bulimia. Intrinsic tooth erosion is due to the chronic performance of gastric acid over the dental surface for a long period of time (MOAZZEZ; BARTLETT, 2014). The extrinsic erosion, is caused by exogenous acids, for example from dietary (BARBOUR; LUSSI, 2014) and drug formulations (HELLWIG; LUSSI, 2014). The main extrinsic etiological factor of erosion is would be derived from acids from the diet. Most of the low pH food and beverages (below 4.5) would have the potential to cause tooth erosion, since at this $\mathrm{pH}$ there is a sub saturation of the oral fluids in relation to hydroxyapatite and fluorapatite (SHELLIS; FEATHERSTONE; LUSSI, 2014). This disorder occurs in patients with, regurgitation, bulimia, rumination and gastroesophageal reflux disease (GERD) (MOAZZEZ; ANGGIANSAH; BARTLETT, 2005). It has been reported that around $10-20 \%$ of the population suffer from GERD (DENT et al., 2005). Considering that the $\mathrm{pH}$ and titratability of gastric acids is greater than those of dietary acids, the destruction of the tooth structure is usually more severe (MOAZZEZ et al., 2005).

All solid surfaces exposed in the oral cavity are covered by a proteinaceous layer called the acquired pellicle (HANNIG, C.; HANNIG; ATTIN, 2005; HANNIG, M.; BALZ, 1999; HANNIG, M.; JOINER, 2006; LENDENMANN; GROGAN; OPPENHEIM, 
2000). It is an organic film, bacterial-free, covering soft and hard tissues. Glycoproteins and proteins, including several enzymes (HANNIG, C.; HAMKENS; et al., 2005; SIQUEIRA; CUSTODIO; MCDONALD, 2012), compose the Acquired Pellicle.

The presence of these organic components, confer important functions to this protein-rich film, such as lubrication, buffering and remineralizing, also acts as a diffusion barrier that reduces dissolution of the tooth.(BUZALAF; HANNAS; KATO, 2012; VUKOSAVLJEVIC et al., 2014). It is remark that part of these proteins remains on the pellicle composition, even after exposure to erosive challenges which makes the acquired pellicle an extreme important factor in the etiology of dental erosion (HANNIG, C. et al., 2009; HANNIG, M.; BALZ, 1999;2001).

There are many studies that focus on the protector impact of the acquired pellicle in the enamel surface (HANNIG, M.; BALZ, 1999;2001; HANNIG, M. et al., 2004; HANNIG, M. et al., 2003; VUKOSAVLJEVIC et al., 2014). Additionally, they also investigated changes in the power of protection along its time of formation of the acquired pellicle, and even with several published studies, there still is many controversies regarding the protective potential of the acquired pellicle as a function of its time of formation. Some previously published studies, has been concluded that the resistance of the acquired pellicle are dependent of time of formation, one study demonstrated pellicles with 2 hours formation, had a fast dissolutions when compares with pellicles formed in 6,12 and 24 hours (HANNIG, M. et al., 2003). It has been suggested, in some studies, that acquired pellicle must reach an ideal thickness, and for a significant protection against the acids challenges, the dental surface must be in contact with saliva for at least 1 hour, and also was verified that protection factor does not significantly increased, if the pellicle through process of maturation for $24 \mathrm{~h}$. In addition, were not found significantly differences in erosives challenges, when the pellicles was formed in $24 \mathrm{~h}$ or 7 days. For Acquired Pellicles formed in short periods of exposure of the dental surface with saliva (less than 30 minutes), apparently the pellicles does not seem to be able to confer good protection against erosion (HANNIG, M.; BALZ, 1999; HANNIG, M. et al., 2003; WETTON et al., 2006). However, some studies are not consistent with previously studies mentioned. An example, studies made in pellicles formed in situ, for 30 min, 1 or 2 hours (HANNIG, M. et al., 2004) or for 2, 6, 12 and 24h (HANNIG, M. et al., 2003), respectively, did not obtain results that significantly differed in the hability of reduce enamel desmineralization. Another study (HANNIG, M. et al., 2004), concluded that is not possible find differences on the effect 
protector of Pellicle formed after 3 minutes when this compares with the pellicle formed in 2 hours. These results can be assigned to the fact that the formation of the Acquired Pellicle, especially in the protein adsorption, that happens seconds after the dental surface enter in contact with salivary proteins (HANNIG, M. et al., 2004), resulting in a basal pellicle electrondense, even after 1 minute of contact (ERICSON et al., 1982). Once that subsequent layers of pellicle are much less electrondense, compares with basal pellicle that seems to offer lack additional protection against acids attack (HANNIG, M. et al., 2004). This is consistent with the observations whereof, after consumed acids beverages, the external globular layers are removed in different extension, according to the localization of the samples in the buccal cavity, while the basal pellicle not affected. In that way, would be interesting knows which proteins compound the basal layer from the acquired Pellicle, that who could be able to protect against acids attack, this justify the pellicle collect formed in short periods.

Since different acids vary in their ability to demineralize bovine enamel (HANNIG, C.; HAMKENS; et al., 2005) the protection from the pellicle formed in situ in the enamel and dentine erosion, caused by hydrochloric, citric and phosphoric acids were analyzed (WIEGAND et al., 2008). Samples of enamel and dentine bovine were exposed by 120 minutes in the oral cavity from 10 healthy volunteers. In sequence, the samples (enamel and dentine) covered by acquired pellicle, were steeped, out of the

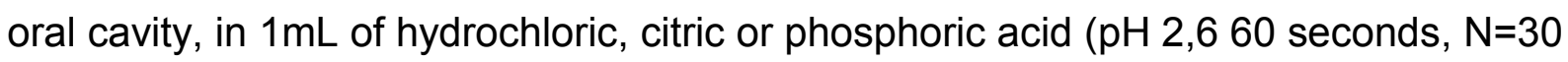
for each type of acid). Samples without covered with pellicle $(N=10)$ were the control group. The calcium release was analysed by atomic absorption spectroscopy. The samples that were covered by acquired pellicle, had calcium loss significantly reduce, when compares to the group control, for all types of acid. Similar findings were obtained in other studies. Were observed a reduction in the calcium loss between 60 and $78 \%$ for enamel samples, eroded by citric acid (1\% for 60 seconds) (HANNIG, M. et al., 2004; HANNIG, M. et al., 2003). To sum up another study in vitro also showed that the acquired pellicle offers significantly protection better for enamel (44\%) than dentine (14\%) (WETTON et al., 2006).

Due to the protector function from the acquired pellicle against acid challenges, fact that are widely reported in the literature (BUZALAF et al., 2012; VUKOSAVLJEVIC et al., 2014) and the observation that even in severs acids challenges (exposed by 5 minutes in citric acid 1\%), the acquired Pellicle is not total removed from the enamel surface (HANNIG, M.; BALZ, 2001; HANNIG, M.; JOINER, 2006). It becomes 
important to investigate the possible components of the pellicle that are most directly associated with the protective potential against tooth erosion, in other words, which proteins remain on the enamel after erosive challenges.

Recently studies by our group has evaluated, using proteomic strategies, which proteins remain adhered to the acquired pellicle formed over the dentin in situ (DELECRODE et al., 2015) and over the enamel in vivo, after citric acid challenge (1\%), simulating extrinsic erosion. In conclusion, it would be interesting to determine the quantitative proteomic profile from acquired pellicles formed in enamel after hydrochloric acids challenges, simulating intrinsic erosion. This becomes of great importance because, recently, it was reported that patients with eating disorders had more risk of erosion ( $\mathrm{Or}=12.4$ ), which is increased when vomiting is self-induced (OR $=19.6$ ). 4 In addition, around 10-20\% of the population suffer from GERD 5 (DENT et al., 2005). In that way, knowledge about which proteins from the acquired pellicle are removal resistant by Hydrochloric acid could be new preventives strategies against intrinsic erosion. In futures studies we could employ procedures that "Acquired Pellicle engineer", leading to a formation of acquired pellicle with that resistant proteins, and making possible better enamel protection against intrinsic erosion, in susceptible patients. These procedures may involve application of mouthwash solutions, toothpaste or gels rich with these acid resistant proteins. 




\section{ARTICLE}

Article formatted according to Journal of Dentistry

Changes in the proteomic profile of acquired enamel pellicle as a function of its time of formation and hydrochloric acid exposure.

Taira EA, Ventura TMS, Cassiano LPS, Silva CMS, Martini T, Leite AL, Magalhães AC, Rios $\mathrm{D}$, Buzalaf MAR*

Bauru School of Dentistry, University of São Paulo, Bauru, SP, Brazil.

Running title: Proteomics of acquired enamel pellicle changes after exposure to $\mathrm{HCl}$

Keywords: Acquired Pellicle; Enamel; dental erosion; gastroesophageal reflux; proteomics.

${ }^{*}$ Corresponding Author: Marília Afonso Rabelo Buzalaf - Department of Biological Sciences, Bauru Dental School, University of São Paulo. Al. Octávio Pinheiro Brisolla, 9-75 Bauru-SP, 17012-901 Brazil. Tel. + 5514 32358346; Fax + 5514 32271486; E-mail: mbuzalaf@fob.usp.br

(to whom reprint requests must be sent) 


\begin{abstract}
Objective: Changes in the protein profile of acquired enamel pellicles (AEP) formed in vivo for different times, after application of hydrochloric acid $(\mathrm{HCl})$ were evaluated. Methods: Nine subjects were submitted to dental prophylaxis with pumice. After 3 or $120 \mathrm{~min}$, the teeth were isolated with cotton rolls and $50 \mu \mathrm{L}$ of $0.1 \mathrm{M} \mathrm{HCl}(\mathrm{pH}=1.0), 0.01 \mathrm{M} \mathrm{HCl}(\mathrm{pH}=2.0)$ or deionized water were applied on the buccal surface of the teeth for $10 \mathrm{~s}$. The AEP was then collected using an electrode filter paper pre-soaked in 3\% citric acid. After protein extraction, the samples were submitted to reverse phase liquid chromatography coupled to mass spectrometry (nLC-ESI-MS/MS). Label-free quantification was performed (Protein Lynx Global Service software). Results: A total of 180 proteins were successfully identified in the AEP samples. The number of identified proteins increased with the time of pellicle formation. Only 4 proteins were present in all the groups (isoforms of IgA, Serum albumin and Statherin). The greatest number of proteins identified uniquely in one of the groups was obtained for the groups treated with $\mathrm{HCl}$ after $2 \mathrm{~h}$ of pellicle formation ( $\sim 50$ proteins). Conclusion: Proteins resistant to removal by $\mathrm{HCl}$, such as Serum Albumin and Statherin, were identified even in the short-term AEP. In addition, 120-min pellicle present many proteins that are resistant to removal by $\mathrm{HCl}$. This suggests an increase in the protection against intrinsic acids along the time of pellicle formation, which should be evaluated in future studies.
\end{abstract}




\section{Introduction}

Dental erosive wear develops ultimately due to the action of non-bacterial acids that initially provoke softening of the dental surface. If the acidic challenge persists, layer-by-layer dissolution of the enamel crystals takes place, with the remaining surface becoming softened [1]. Despite the lesion itself is caused by acids, erosive wear is in fact a multifactorial condition developed due to a complex interaction of factors related to the patient combined with nutritional factors. The etiology is also influenced by other factors such as education, behavior, occupation, knowledge, employment and general health [2]. Among the factors related to the patient are some conditions that lead to the return of gastric acids, also known as intrinsic acids, to the oral cavity. This occurs in patients with bulimia, regurgitation, rumination and gastroesophageal reflux disease (GERD) [3]. Recently, it was reported that patients with eating disorders had more risk of erosion ( $\mathrm{Or}=12.4)$, which is increased when vomiting is selfinduced $(\mathrm{OR}=19.6)$. [4] In addition, around $10-20 \%$ of the population suffer from GERD [5]. Considering that the $\mathrm{pH}$ and titratability of gastric acids is greater than those of dietary acids, the destruction of the tooth structure is usually more severe [3], which means that preventive and therapeutic measures are necessary.

One of the most important preventive factors against erosive wear is saliva, since it is supersaturated with respect to hydroxyapatite, has the potential to clean the oral cavity, washing out the acids, and contributes to the formation of the acquired enamel pellicle (AEP) [6]. The AEP is a bacteria-free organic film that covers the hard and soft tissues in the oral cavity. It is composed mainly by proteins and glycoproteins [7], but it also contains lipids [8]. These organic components confer important functions to the AEP, such as lubrication and protection of the underlying tooth surface. The AEP also acts as a diffusion barrier that reduces the direct contact between the acids and the tooth surface, thus reducing the degree of dissolution of the tooth $[6$, 9]. Most of the protective ability of the AEP against acidic dissolution of the teeth derives from its protein composition. It is noteworthy that part of the pellicle remains on the tooth surface, even after severe erosive challenges $[10,11]$. Recently, proteomic tools were employed to identify proteins within the AEP that are resistant to removal by citric acid [12]. These acidresistant proteins seem to have good potential to prevent tooth dissolution under acidic conditions. However, proteins resistant to removal by hydrochloric acid $(\mathrm{HCl})$, the main constituent of the gastric juice, have never been identified so far, which was the main aim of the present study. Additionally, we also investigated changes in the protein profile of the AEP 
along its time of formation, both under normal conditions and after challenges with two concentrations of $\mathrm{HCl}$. The null hypotheses tested were that the protein composition of the AEP does not change as a function of its time of formation neither after exposure to different concentrations of $\mathrm{HCl}$.

\section{Materials and Methods}

\section{Ethical Aspects and Subjects}

Nine young (18-35 years old) adult subjects ( 2 male, 7 female) participated in this crossover study, approved by the local Institutional Ethics Committee (No. 44737115.4.0000.5417). Subjects signed an informed consent document prior to the beginning of the study. Sample size was based on in vivo studies conducted with similar research protocol $[12,13]$. The inclusion criteria were: non-smokers, good oral (without caries, gingivitis, periodontitis and other oral conditions that could affect the composition of oral fluid), good general health and no restorative treatment on the buccal surface of the upper and lower teeth. Participants who had risk factors for dental erosion, such as excessive consumption of carbonated drinks, fruit juices or acidic fruits, swimmers, or that had gastric disorders such as bulimia and gastroesophageal reflux were excluded. In addition, pregnant women, patients with systemic diseases and using chronic medication were not eligible to participate. Volunteers stimulated salivary flow was higher than $1 \mathrm{~mL} / \mathrm{min}$ and the unstimulated salivary flow was higher than $0.25 \mathrm{~mL} / \mathrm{min}$. Following a crossover protocol, each volunteer took part in all the groups under study. The factors under study were the time of formation of the AEP in two levels ( $3 \mathrm{~min}$ or $2 \mathrm{~h}$, in order to analyse the proteins present in the basal layer and in the subsequent layers, respectively[14]) and the type of treatment solution applied over the AEP in three levels: deionized water, $0.01 \mathrm{M} \mathrm{HCl}(\mathrm{pH} 2.0)$ or $0.1 \mathrm{M} \mathrm{HCl}(\mathrm{pH} 1.0)$, totalling 6 groups (Water-3min, Water-2h, pH2-3min, $\mathrm{pH} 2-2 \mathrm{~h}, \mathrm{pH} 1-3 \mathrm{~min}$ and $\mathrm{pH} 1-2 \mathrm{~h}$ ). The $\mathrm{HCl}$ concentrations of 0.1 and 0.01 $\mathrm{M}$ were chosen because they correspond to $\mathrm{pH} 1$ and 2, respectively and the $\mathrm{pH}$ of the gastric juice typically ranges between 1 and 3 [15]. For each volunteer, AEP was collected on 12 different days ( 2 days for each of the six groups/treatments), as detailed below. 
$\underline{\text { AEP Formation and Collection }}$

In order to avoid circadian effects on the composition of the pellicle, the experiment began in the morning each day [16]. The subjects underwent a dental prophylaxis employing coarse pumice containing no additives. The volunteers waited 3 or $120 \mathrm{~min}$ deprived of food and beverage consumption, to allow the formation of acquired pellicle on enamel [17]. After the periods allowed for the formation of the AEP ( 3 or $120 \mathrm{~min}$ ), each quadrant of the mouth was rinsed with deionized water and dried with compressed air twice and isolated with cotton rolls. Then $50 \mu \mathrm{L}$ of deionized water, $0.1 \mathrm{M} \mathrm{HCl}(\mathrm{pH} 1)$ or $0.01 \mathrm{M} \mathrm{HCl}(\mathrm{pH} 2)$, depending on the phase under study, was gently applied with a pipette on the buccal surface of the upper and lower teeth (from second molar to second molar in each arch) for $10 \mathrm{sec}$. The solutions were carefully removed with deionized water using the dental syringe and the teeth were air-dried [12]. The remaining AEP was then collected with the aid of $5 \times 10 \mathrm{~mm}$ electrode filter paper (Bio-Rad, Hercules, CA) pre-dipped in 3\% citric acid (pH 2.5; Sigma-Aldrich, USA). The filter paper was rubbed (without pressure) on the coronal two-thirds (to avoid contamination of the gingival margin) of the buccal surfaces of the teeth with tweezers [17]. The wick filters were placed in $2 \mathrm{~mL}$ cryotubes and stored at $-80^{\circ} \mathrm{C}$ until prepared for proteomic analysis. The filters collected from all the participants on two different days, corresponding to the same treatment and time of pellicle formation were pooled in order to have enough material to be analysed. Six pools were obtained, corresponding to the 6 groups.

\section{Preparation of the AEP samples}

The AEP samples were prepared as previously reported [18].The Eppendorf tubes containing the filter papers were removed from the $-80^{\circ} \mathrm{C}$ freezer. After defrost, the papers were cut into small pieces, using sterile scissors and tweezers. These pieces were kept together in an Eppendorf tube, constituting a pool for each group. Approximately $400 \mu \mathrm{L}$ (until the papers were covered) of a solution containing $6 \mathrm{M}$ urea, $2 \mathrm{M}$ thiourea in $\mathrm{NH}_{4} \mathrm{HCO}_{3} 50 \mathrm{mM} \mathrm{pH}$ 7.8 was added to each tube, vortexed for 10 minutes at $4{ }^{\circ} \mathrm{C}$, sonicated for 5 minutes and centrifuged for 10 minutes at $14,000 \mathrm{~g}$ at $4^{\circ} \mathrm{C}$. The supernatant was collected and transferred to a new tube. This procedure was repeated once more. The papers were then placed in tube filters (Corning Costar ${ }^{\circledR}$ Spin-X ${ }^{\circledR}$ Plastic Centrifuge Tube Filters, Sigma-Aldrich, New York, USA) and centrifuged at $14,000 \mathrm{~g}$ for 10 minutes at $4^{\circ} \mathrm{C}$. The supernatant was recovered, added to 
that collected previously and centrifuged once more at $14,000 \mathrm{~g}$ at $4^{\circ} \mathrm{C}$. The supernatant was transferred to a $15-\mathrm{ml}$ falcon tube. In sequence, $50 \mathrm{mM} \mathrm{NH}_{4} \mathrm{HCO}_{3}$ (1.5 X the sample volume) was added to dilute the urea and thiourea. The samples were transferred to Falcon Amicon tubes (Amicon Ultra - 15 Centrifugal Filter Units - Merck Millipore, Tallagreen, Ireland), centrifuged at $5,000 \mathrm{~g}$ at $4^{\circ} \mathrm{C}$ and concentrated to approximately $150 \mu \mathrm{L}$. Reduction was then performed by adding $5 \mathrm{mM}$ dithiothreitol (DTT) followed by incubation for $40 \mathrm{~min}$ at $37^{\circ} \mathrm{C}$. Samples were then alkylated by adding $10 \mathrm{mM}$ iodoacetamide (IAA) and incubated in the dark for $30 \mathrm{~min}$. In sequence, $100 \mu \mathrm{L}$ of $50 \mathrm{mM} \mathrm{NH}_{4} \mathrm{HCO}_{3}$ was added and samples were digested for $14 \mathrm{~h}$ at $37^{\circ} \mathrm{C}$ by adding $2 \%(\mathrm{p} / \mathrm{p})$ trypsin (Promega, Madison, USA). Then $10 \mu \mathrm{L}$ of $5 \%$ formic acid was added to stop the action of trypsin. Samples were then desalted and purified using C18 Spin columns (Thermo Scientific, USA). Then an aliquot of $1 \mu \mathrm{L}$ of each sample was removed and protein quantification was performed using the Bradford method (Bio-Rad Bradford Assays, USA). The total amount of protein recovered ranged between 63 and $115 \mu \mathrm{g}$ for the different groups. The samples were resuspended in a solution containing $3 \%$ acetonitrile and $0.1 \%$ formic acid to be submitted to nano LC-ESI-MS / MS.

\section{$\underline{\text { Shotgun Label-free Quantitative Proteomic Analysis }}$}

Peptides identification was performed on a nanoACQUITY UPLC-Xevo QTof MS system (Waters, Manchester, UK). The nanoACQUITY UPLC was equipped with nanoACQUITY HSS T3, analytical reverse phase column $(75 \mu \mathrm{m}$ X $150 \mathrm{~mm}, 1.8 \mu \mathrm{m}$ particle size, Waters). The column was equilibrated with mobile phase A ( $0.1 \%$ formic acid in water). The peptides were separated with a linear gradient of $7-85 \%$ mobile phase B $(0.1 \%$ formic acid in $\mathrm{ACN}$ ) for $70 \mathrm{~min}$ at a flow rate of $0.35 \mu \mathrm{L} / \mathrm{min}$. The column temperature was kept at $55^{\circ} \mathrm{C}$. The Xevo G2 Q-TOF mass spectrometer was operated in positive nanoelectrospray ion mode and data were collected using the MSE method in elevated energy (19-45 V), which allows data acquisition of both precursor and fragment ions, in one injection. Source conditions used included capillary voltage, $2.5 \mathrm{kV}$; sample cone, $30 \mathrm{~V}$; extraction cone, $5.0 \mathrm{~V}$ and source temperature, $80^{\circ} \mathrm{C}$. Data acquisition occurred over $70 \mathrm{~min}$ and the scan range was 50-2000 Da. The lock spray, used to ensure accuracy and reproducibility, was run with a [Glu1] fibrinopeptide solution ( $1 \mathrm{pmol} / \mu \mathrm{L})$ at a flow rate of $1 \mu \mathrm{L} / \mathrm{min}$, as a reference ion in positive mode at m/z 785.8427. ProteinLynx Global Server (PLGS) version 3.0 was used to process and 
search the continuum LC-MSE data. Proteins were identified with the embedded ion accounting algorithm in the software and a search of the Homo sapiens database (reviewed only, UniProtKB/Swiss-Prot) downloaded on May 2016 from UniProtKB (http://www.uniprot.org/). The identified proteins were classified and assigned by biological function $[16,18,19]$, origin and molecular interaction (http://www.uniprot.org/).

For label-free quantitative proteome, three MS raw files from each pooled group were analysed using the Protein Lynx Global Service (PLGS, v 2.2.5, Waters Co., Manchester, UK) software. All the proteins identified with a score with confidence greater than $95 \%$ were included in the quantitative analysis. Identical peptides from each triplicate by sample were grouped based on mass accuracy $(<10 \mathrm{ppm})$ and on time of retention tolerance $<0.25 \mathrm{~min}$, using the clustering software embedded in the PLGS. Difference in expression among the groups was expressed as $\mathrm{p}<0.05$ for down-regulated proteins and $1-\mathrm{p}>0.95$ for up-regulated proteins. The following relevant comparisons were made: Water- $2 \mathrm{~h} \mathrm{X}$ Water-3min, $\mathrm{pH} 2-2 \mathrm{~h} \mathrm{X} \mathrm{pH2-3min,}$ pH1-2h X pH1-3min, Water-3min X pH2-3min, pH2-2h X Water-2h, pH1-3min X Water3min, pH1-2h X Water-2h, pH1-3min X pH2-3min, pH1-2h X pH2-2h.

\section{Results}

The identified proteins when classified according to their function, molecular interaction and origin are displayed in Tables 1 and 2 and Supplementary table (S1). In total, 180 proteins were identified (Table S1). Figure 1 shows the number of proteins common to the distinct groups, as well as the numbers of proteins found in only one of the groups. Four proteins were identified in all the groups (Ig alpha-1 chain C region, Ig alpha-2 chain C region, Serum albumin and Statherin; Figure 1, Table S1). The number of identified proteins increased with the time of pellicle formation (Table S1). Fifteen proteins were found only in groups with $2 \mathrm{~h}$ of formation, such as Lysozyme C, Myeloperoxidase, Protein S100-A8, Lactotransferrin and isoforms of keratin. Many proteins (140) were found exclusively in one of the groups: 13 in Water-3min, 28 in Water-2h, 1 in pH2-3min, 47 in $\mathrm{pH} 2-2 \mathrm{~h}$ and 52 in $\mathrm{pH} \mathrm{1-2h.} \mathrm{No} \mathrm{unique}$ protein was identified in the group $\mathrm{pH} 1-3 \mathrm{~min}$ (Table 1).

Regarding quantitative analysis, nine comparisons were made among the six groups (Table 2). For the group treated with water (comparison Water-2h X Water 3-min), along time there was an increase in Actin cytoplasmic 2, Neutrophil defensin 3, Actin cytoplasmic 1, Neutrophil defensin 1 and a decrease in Cystatin-SN. When the AEP was challenged with $\mathrm{HCl}$ $\mathrm{pH}$ 2, along time (comparison $\mathrm{pH} 2-2 \mathrm{~h} \mathrm{X} \mathrm{pH2-3} \mathrm{min)} \mathrm{there} \mathrm{was} \mathrm{an} \mathrm{increase} \mathrm{in} \mathrm{Serum} \mathrm{albumin}$ 
and decrease in Statherin, Ig alpha-2 chain C region and Ig alpha-1 chain C region. Serum albumin also increased along time when the AEP was challenged with $\mathrm{HCl} \mathrm{pH}$ 1(comparison pH1-2h X pH1-3min). Besides Serum albumin, Statherin, Ig alpha-1 chain C region an Ig alpha-2 chain $C$ region also increased in this comparison.

When the groups treated with $\mathrm{HCl}$ at different $\mathrm{pH}$ were compared, for the short-term pellicle under stronger challenge (comparison $\mathrm{pH} 1-3 \mathrm{~min} \mathrm{X} \mathrm{pH2-3min)} \mathrm{there} \mathrm{was} \mathrm{an} \mathrm{increase}$ in Serum albumin only that was also increased in the long-term pellicle (comparison $\mathrm{pH} 1-2 \mathrm{~h}$ $\mathrm{X} \mathrm{pH2-2h).} \mathrm{In} \mathrm{this} \mathrm{comparison,} \mathrm{there} \mathrm{was} \mathrm{also} \mathrm{an} \mathrm{increase} \mathrm{in} 9$ other proteins, including Cystatin-SN, Lysozyme C, Statherin and isoforms of IgA and keratin. On the other hand, for this comparison there was a decrease in 11 proteins, including Protein S100-A8, Neutrophil defensin 3 and isoforms of actin and POTE Ankyrin (Table 2).

\section{Discussion}

The main aim of this study was to identify proteins in the AEP that are resistant to removal by $\mathrm{HCl}$, an intrinsic acid that is found in the oral cavity after episodes of gastroesophageal reflux, vomiting and bulimia. The identification of these acid-resistant proteins is of utmost importance, since they have a great potential to protect the teeth after acidic challenges. A secondary aim was to evaluate changes in the protein profile of the AEP along its time of formation, both under normal conditions as well as after challenges with $\mathrm{HCl}$. It was observed an increase in the number of proteins identified in the AEP along time, which is expected and has been reported in a previous study [13]. Some proteins were identified only in the groups with 2 hours of AEP formation, such as Lysozyme C, Myeloperoxidase, Protein S100-A8, Lactotransferrin and isoforms of keratin, which suggests that these proteins probably do not bind to hydroxyapatite but bind to the precursor proteins. An interesting finding of the present study was that only quite few proteins were identified in the 3-min pellicle after challenge with $\mathrm{HCl}$ (mainly Immunoglobulins, Serum Albumin and Statherin). Since it has been reported no difference in the protective effect against acids of a pellicle formed after three minutes compared to one formed after two hours [14], it is possible that these proteins are responsible for most of the protection conferred by the short-term pellicle. It should be 
highlighted, however, that this study [14] was conducted in situ and that the acidic challenge was performed with orange juice, while the present study had an in vivo design and the acidic challenge was done with $\mathrm{HCl}$.

We employed an in vivo design that had been used before to evaluate proteins in the AEP that are resistant to removal by acids that mimic extrinsic erosion (citric acid) and caries (lactic acid) [12]. Thus, the results obtained here are more realistic than those described in studies involving in vitro [20-22] or in situ [23] protocols. The preparation of the AEP for MS was done according to a recently developed methodology that increases the identification of proteins in the AEP samples [18]. This allowed the identification of 180 proteins. From these, four deserve special attention because they were present in all the groups, regardless of the time of pellicle formation, and even after exposure to $\mathrm{HCl}$ : Statherin, Serum Albumin and isoforms of Ig alpha. Statherin is a 43-residue phosphorylated salivary protein with primary sequence similarities to osteopontin and casein that binds calcium and hydroxyapatite. Its negative charge density and helical conformation at the N-terminus are important for the interaction with hydroxyapatite [24]. This interaction seems to be strong, since not even challenge with $0.1 \mathrm{M}$ $\mathrm{HCl}$ was able to detach this protein from the enamel surface. In fact, solid-state nuclear magnetic resonance (NMR) studies confirmed that the N-terminus of Statherin strongly binds to hydroxyapatite, while the middle and C-terminal regions are mobile and dynamic [25]. In order to protect against demineralization, it is suggested that statherin-like peptides containing at least $15 \mathrm{~N}$-terminal residues or more, are required [26]. It was recently reported that the calcium concentration in the AEP of patients with dental erosion is $50 \%$ reduced, while the concentration of Statherin is 35\% reduced [27]. This emphasizes the potential of this protein to protect against dental erosion. Another protein that was identified in all the conditions was Serum Albumin, which comes from plasma and it is able to bind ions as calcium [28]. This can also be important for acid protection, since ovalbumin was shown to reduce the dissolution of hydroxyapatite by acid solutions in vitro [29, 30]. These results indicate that Albumin and Statherin are resistant to removal by $\mathrm{HCl}$. These proteins are then potential candidates to be included in anti-erosion dental products. The presence of Ig alpha among these proteins deserves further investigation, since at the moment this protein has not been related to resistance of enamel against erosive demineralization.

Interestingly, the greatest number of proteins identified uniquely in one of the groups was found for the groups treated with $\mathrm{HCl}$ after $2 \mathrm{~h}$ of pellicle formation (around 50 proteins for each of these groups). This means that many proteins remain in the AEP after exposure to $\mathrm{HCl}$, even at low $\mathrm{pH}$. The fact the groups treated with $\mathrm{HCl}$ had a higher number of proteins than 
the group treated with deionized water might be related to the fact that $\mathrm{HCl}$ might remove at least part of the most abundant proteins, thus allowing that the present in much lower amounts can be detected by mass spectrometry. Furthermore, it should be highlighted that potentially protective proteins, such as Serum albumin (both for $\mathrm{HCl} \mathrm{pH} 1$ and $\mathrm{HCl} \mathrm{pH}$ 2) and Statherin (for $\mathrm{HCl} \mathrm{pH} \mathrm{1)} \mathrm{increased} \mathrm{along} \mathrm{time} \mathrm{of} \mathrm{formation} \mathrm{after} \mathrm{application} \mathrm{of} \mathrm{HCl}$. As mentioned above, an in situ study employing orange juice to perform the erosive challenge did not find any difference in the protective effect of AEPs formed after three minutes or two hours [14]. It must be taken into account that the $\mathrm{pH}$ of $\mathrm{HCl}$ is lower than that of orange juice. Thus, it is possible that for the AEP challenged with intrinsic acid $(\mathrm{HCl})$, a long time of maturation is important for the protection against demineralization. In line with this hypothesis, an in situ study showed that exposure to saliva for $30 \mathrm{~min}$ for AEP formation promoted less enamel resistance to $\mathrm{HCl}$ erosive attack than exposure to saliva for 2 hours [31]. This suggests that more mature pellicles might provide higher protection against intrinsic erosion than short-term pellicle.

In conclusion, the present study identified potentially protective proteins that are resistant to removal by $\mathrm{HCl}$ even in the short-term AEP, such as Serum Albumin and Statherin. In addition, it was observed that the mature pellicles present many proteins that are resistant to removal by $\mathrm{HCl}$, even at $\mathrm{pH} 1$. This suggests that there is an increase in the protection against intrinsic acids along the time of pellicle formation, which should be evaluated in future studies. 


\section{References}

[1] A. Lussi, N. Schlueter, E. Rakhmatullina, C. Ganss, Dental erosion--an overview with emphasis on chemical and histopathological aspects, Caries Res. 45 Suppl 1 (2011) 2-12.

[2] A. Lussi, T.S. Carvalho, Erosive tooth wear: a multifactorial condition of growing concern and increasing knowledge, Monographs in oral Sci. 25 (2014) 1-15.

[3] R. Moazzez, D. Bartlett, Intrinsic causes of erosion, Monographs in oral Sci. 25 (2014) 18096.

[4] A.P. Hermont, P.A. Oliveira, C.C. Martins, S.M. Paiva, I.A. Pordeus, S.M. Auad, Tooth erosion and eating disorders: a systematic review and meta-analysis, PloS One. 9(11) (2014) e111123.

[5] J. Dent, H.B. El-Serag, M.A. Wallander, S. Johansson, Epidemiology of gastro-oesophageal reflux disease: a systematic review, Gut 54(5) (2005) 710-7.

[6] M.A.R. Buzalaf, A.R. Hannas, M.T. Kato, Saliva and dental erosion, J Appl Oral Sci 20(5) (2012) 493-502.

[7] W.L. Siqueira, W. Custodio, E.E. McDonald, New Insights into the Composition and Functions of the Acquired Enamel Pellicle, J Dent Res 91(12) (2012) 1110-1118.

[8] B.L. Slomiany, V.L. Murty, E. Zdebska, A. Slomiany, K. Gwozdzinski, I.D. Mandel, Tooth surface-pellicle lipids and their role in the protection of dental enamel against lactic-acid diffusion in man, Arch Oral Biol. 31(3) (1986) 187-91.

[9] D. Vukosavljevic, W. Custodio, M.A.R. Buzalaf, A.T. Hara, W.L. Siqueira, Acquired pellicle as a modulator for dental erosion, Arch Oral Biol. 59(6) (2014) 631-638.

[10] C. Hannig, D. Berndt, W. Hoth-Hannig, M. Hannig, The effect of acidic beverages on the ultrastructure of the acquired pellicle--an in situ study, Arch Oral Biol. 54(6) (2009) 518-26.

[11] M. Hannig, M. Balz, Protective properties of salivary pellicles from two different intraoral sites on enamel erosion, Caries Res. 35(2) (2001) 142-8.

[12] T.R. Delecrode, W.L. Siqueira, F.C. Zaidan, M.R. Bellini, E.B. Moffa, M.C. Mussi, Y. Xiao, M.A. Buzalaf, Identification of acid-resistant proteins in acquired enamel pellicle, J Dent. 43(12) (2015) 1470-5.

[13] Y.H. Lee, J.N. Zimmerman, W. Custodio, Y. Xiao, T. Basiri, S. Hatibovic-Kofman, W.L. Siqueira, Proteomic evaluation of acquired enamel pellicle during in vivo formation, PloS One. 8(7) (2013) e67919.

[14] M. Hannig, M. Fiebiger, M. Guntzer, A. Dobert, R. Zimehl, Y. Nekrashevych, Protective effect of the in situ formed short-term salivary pellicle, Arch Oral Biol. 49(11) (2004) 903-10. 
[15] A. Milosevic, D.A. Brodie, P.D. Slade, Dental erosion, oral hygiene, and nutrition in eating disorders, Int J Eat Disord. 21(2) (1997) 195-9.

[16] J.N. Zimmerman, W. Custodio, S. Hatibovic-Kofman, Y.H. Lee, Y. Xiao, W.L. Siqueira, Proteome and peptidome of human acquired enamel pellicle on deciduous teeth, Int J Mol Sci. 14(1) (2013) 920-34.

[17] W.L. Siqueira, W. Zhang, E.J. Helmerhorst, S.P. Gygi, F.G. Oppenheim, Identification of protein components in in vivo human acquired enamel pellicle using LC-ESI-MS/MS, J Proteome Res. 6(6) (2007) 2152-60.

[18] T.M.S. Ventura, L.P.S. Cassiano, C.M.S. Silva, E.A. Taira, A.L. Leite, D. Rios, M.A.R. Buzalaf, The proteomic profile of the acquired enamel pellicle changes according to its location in the dental arches, Arch Oral Biol. 79 (2017) 20-29.

[19] S.C. Rison, T.C. Hodgman, J.M. Thornton, Comparison of functional annotation schemes for genomes, Funct Integ Genomics. 1(1) (2000) 56-69.

[20] W.L. Siqueira, M. Bakkal, Y. Xiao, J.N. Sutton, F.M. Mendes, Quantitative proteomic analysis of the effect of fluoride on the acquired enamel pellicle, PloS One. 7(8) (2012) e42204. [21] W. Custodio, W.J. Silva, A.F. Paes Leme, J.A. Cury, A.A. Del Bel Cury, Plasma proteins in the acquired denture pellicle enhance substrate surface free energy and Candida albicans phospholipase and proteinase activities, J Investig Clin Dent. 6(4) (2015) 273-81.

[22] N. Masson, R.R. Domingues, J.A. Cury, A.F.P. Leme, Acidulated Phosphate Fluoride Application Changes the Protein Composition of Human Acquired Enamel Pellicle, Caries Res. 47(3) (2013) 251-258.

[23] T.R. Delecrode, W.L. Siqueira, F.C. Zaidan, M.R. Bellini, A.L. Leite, Y. Xiao, D. Rios, A.C. Magalhaes, M.A. Buzalaf, Exposure to acids changes the proteomic of acquired dentine pellicle, J Dent. 43(5) (2015) 583-8.

[24] P.A. Raj, M. Johnsson, M.J. Levine, G.H. Nancollas, Salivary statherin. Dependence on sequence, charge, hydrogen bonding potency, and helical conformation for adsorption to hydroxyapatite and inhibition of mineralization, J Biol Chem. 267(9) (1992) 5968-76.

[25] G.A. Naganagowda, T.L. Gururaja, M.J. Levine, Delineation of conformational preferences in human salivary statherin by $1 \mathrm{H}, 31 \mathrm{P}$ NMR and CD studies: sequential assignment and structure-function correlations, J Biomol Struct Dyn. 16(1) (1998) 91-107.

[26] S. Shah, J. Kosoric, M.P. Hector, P. Anderson, An in vitro scanning microradiography study of the reduction in hydroxyapatite demineralization rate by statherin-like peptides as a function of increasing N-terminal length, Eur J Oral Sci. 119 Suppl 1 (2011) 13-8. 
[27] G. Carpenter, E. Cotroneo, R. Moazzez, M. Rojas-Serrano, N. Donaldson, R. Austin, L. Zaidel, D. Bartlett, G. Proctor, Composition of enamel pellicle from dental erosion patients, Caries Res. 48(5) (2014) 361-7.

[28] H. Schweigel, M. Wicht, F. Schwendicke, Salivary and pellicle proteome: A datamining analysis, Sci Rep. 6 (2016) 38882.

[29] C.A. Hemingway, R.P. Shellis, D.M. Parker, M. Addy, M.E. Barbour, Inhibition of hydroxyapatite dissolution by ovalbumin as a function of $\mathrm{pH}$, calcium concentration, protein concentration and acid type, Caries Res. 42(5) (2008) 348-53.

[30] J. Kosoric, M.P. Hector, P. Anderson, The influence of proteins on demineralization kinetics of hydroxyapatite aggregates, J Biomed Mater Res A. 94(3) (2010) 972-7.

[31] F.L. Mendonca, M.C. Jordao, F.Q. Ionta, M.A. Buzalaf, H.M. Honorio, L. Wang, D. Rios, In situ effect of enamel salivary exposure time and type of intraoral appliance before an erosive challenge, Clin Oral Investig. (2017). 


\section{Figure legend}

Figure 1. Organogram showing the number of proteins identified in the acquired enamel pellicle collected after different times of formation ( 3 minutes or 2 hours) and treatments (Water, $\mathrm{HCl} \mathrm{pH} 2$ or $\mathrm{HCl} \mathrm{pH}$ 1).

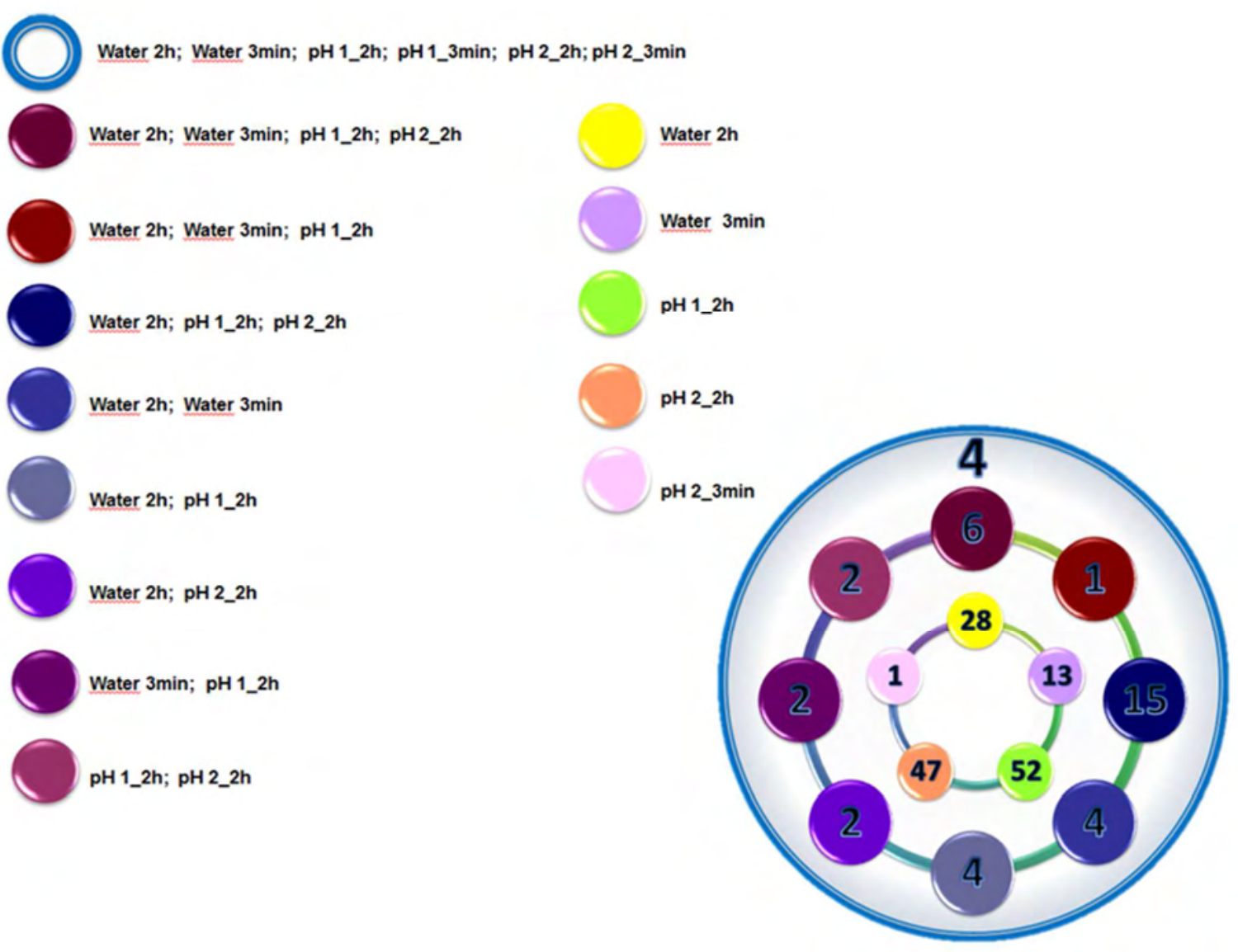


Table 1. Classification of the proteins identified in only one of the groups.

\begin{tabular}{|c|c|c|c|}
\hline Water 3 minutes & Accession name & Protein name and Classification & PLGS Score \\
\hline & 075419 & Cell division control protein 45 homolog (a. b. g. . . p. u. w) & 62.00 \\
\hline & 043187 & Interleukin-1 receptor-associated kinase-like $2^{\text {(b. g.j. . . p. s. s. u) }}$ & 54.33 \\
\hline & Q13485 & Mothers against decapentaplegic homolog 4 (f. g. . . . . . . p. u. w) & 110.93 \\
\hline & D6RGX4 & Protein FAM90A26 (b. m.t.u) & 34.91 \\
\hline & Q9P1P4 & Putative trace amine-associated receptor $3^{\text {(b. . . m. . s.x) }}$ & 41.63 \\
\hline & F8WDV7 & RING finger protein $121^{\text {(b. c. m. s. u. w) }}$ & 104.86 \\
\hline & Q13126 & S-methyl-5'-thioadenosine phosphorylase (a. b. g. n. p. u. w) & 127.04 \\
\hline & A6NLX3 & Speedy protein E4 (b.g.t.w) & 144.9 \\
\hline & Q96NU1 & Sterile alpha motif domain-containing protein $11^{\text {(e.m. p. u) }}$ & 46.14 \\
\hline & Q7Z7G0 & Target of Nesh-SH3 (b.d. m. o. u. w) & 67.43 \\
\hline & Q9NNW7 & Thioredoxin reductase 2. mitochondrial (a. b. g. . . u. w) & 42.25 \\
\hline & $\mathrm{F} 2 \mathrm{Z} 2 \mathrm{~F} 3$ & Uncharacterized protein ${ }^{(b .} \mathrm{m}$. n. w) & 127.04 \\
\hline & P25311 & Zinc-alpha-2-glycoprotein (a. b. . .o. u. w) & 62.92 \\
\hline
\end{tabular}




\begin{tabular}{|c|c|c|c|}
\hline Water 2 hours & Accession name & Protein name and Classification & PLGS Score \\
\hline & P22303 & Acetylcholinesterase (a. e. g. o. s. u. w) & 56.19 \\
\hline & P03973 & Antileukoproteinase (a. g.j. o. u) & 127.13 \\
\hline & Q6PIW4 & Fidgetin-like protein $1^{\text {(a. b. . . h. p. u.w) }}$ & 77.58 \\
\hline & H7BXF5 & Histone deacetylase complex subunit SAP130 (a. b. g. p. u) & 97.64 \\
\hline & P31276 & Homeobox protein $\mathrm{Hox}-\mathrm{C} 13$ (b.e.g. p. u) & 92.86 \\
\hline & Q5TA45 & Integrator complex subunit 11 (b.e.g. .n. p.u) & 139.67 \\
\hline & Q5JVA3 & Interleukin-15 receptor subunit alpha (Fragment) ${ }^{\text {(b.e. h.j. p. u) }}$ & 125.69 \\
\hline & F8W0C6 & Keratin. type II cytoskeletal 5 (Fragment) ${ }^{\text {(d. h. . o. p. u. w) }}$ & 119.78 \\
\hline & Q9NSKO & Kinesin light chain 4 (a.c. g. n. u) & 145.84 \\
\hline & Q8WV93 & Lactation elevated protein 1 (a. g. n. u) & 96.68 \\
\hline & 043148 & mRNA cap guanine-N7 methyltransferase (a. e. g. p. u) & 130.73 \\
\hline & E9PK18 & Rho GTPase-activating protein $27^{\text {(a. b. e. e. . . . s. u) }}$ & 267.7 \\
\hline & Q15633 & RISC-loading complex subunit TARBP2 (f. g. n. p. u. w) & 191.49 \\
\hline & Q9C013 & Serine-rich coiled-coil domain-containing protein $1^{\text {(b. m.t. u) }}$ & 179.96 \\
\hline & I3LOM1 & Sex hormone-binding globulin (b. m. o. u. w) & 107.92 \\
\hline & 076082 & Solute carrier family 22 member 5 (f. g. s. u. w) & 115.98 \\
\hline & 000338 & Sulfotransferase $1 C 2$ (a. b. g. n. u. w) & 129.21 \\
\hline
\end{tabular}




\begin{tabular}{|c|c|c|c|}
\hline & B8ZZF7 & Sulfotransferase ${ }^{\text {(b. m. t.x) }}$ & 129.21 \\
\hline & P60508 & Syncytin-2 ${ }^{\text {(b. m. s. u. w) }}$ & 79.25 \\
\hline & Q12799 & T-complex protein 10A homolog (b. m. n. u) & 91.62 \\
\hline & X6REB3 & Transcription factor E2-alpha (f. g. p. u. w) & 76.38 \\
\hline & P07437 & Tubulin beta chain (b. d. m. n. q. u. w) & 100.25 \\
\hline & Q13885 & Tubulin beta-2A chain (b.d.m. n.q. u.w) & 100.25 \\
\hline & Q9BVA1 & Tubulin beta-2B chain (b. d. m. n. q. u. w) & 100.25 \\
\hline & P04350 & Tubulin beta-4A chain (b. d. m. n. q. u. w) & 100.25 \\
\hline & P68371 & Tubulin beta- $4 B$ chain ${ }^{\text {(b. d. m. n. q. u. w) }}$ & 100.25 \\
\hline & Q96KH6 & Uncharacterized protein C18orf12 (b. m.t.w) & 109.41 \\
\hline & F8WOF8 & Voltage-dependent L-type calcium channel subunit beta-3 ${ }^{\text {(f. g. n. s. v. u) }}$ & 157.48 \\
\hline pH 2 - 3 minutes & Accession name & Protein name and Classification & \\
\hline & Q9UBC2 & Epidermal growth factor receptor substrate 15 -like $1^{\text {(b.c. c. p. p. s. u.v) }}$ & \\
\hline pH 2_2 hours & Accession name & Protein name and Classification & \\
\hline & Q8TE56 & A disintegrin and metalloproteinase with thrombospondin motifs $17^{\text {(b. m. o. u) }}$ & \\
\hline & Q5T085 & Alpha-amylase (Fragment) ${ }^{\text {(a.m.t.u) }}$ & \\
\hline & P04745 & Alpha-amylase $1^{\text {(a. g. o. u) }}$ & \\
\hline & P19961 & Alpha-amylase $2 B^{\text {(a. g. o. u) }}$ & \\
\hline
\end{tabular}




\begin{tabular}{|c|c|}
\hline Q6NXT1 & Ankyrin repeat domain-containing protein 54 (a. b. c. e. g. n. p. u) \\
\hline G5E9V7 & Armadillo repeat containing 8. isoform CRA_d ${ }^{\text {(m. t. u) }}$ \\
\hline G5E9V6 & Armadillo repeat containing 8 . isoform CRA_e ${ }^{\text {(b. m.t.u) }}$ \\
\hline Q8IUR7 & Armadillo repeat-containing protein $8^{\text {(f. m.t. u) }}$ \\
\hline Q9H4G0 & Band 4.1-like protein 1 (a. b. g. p. u) \\
\hline Q9NXV6 & CDKN2A-interacting protein (a. b. g. m. p. u. w) \\
\hline P18847 & Cyclic AMP-dependent transcription factor ATF-3 (a. b. e. g. h. p. u) \\
\hline E9PDJ4 & Dedicator of cytokinesis protein 8 (f. m. n. s. u. u. w) \\
\hline Q8IYM9 & E3 ubiquitin-protein ligase TRIM22 (a.t. g. i. n. p. u.w) \\
\hline F6RJU0 & Enoyl-CoA hydratase domain-containing protein 2. mitochondrial (a. b. m.t.x) \\
\hline Q9NQT5 & Exosome complex component RRP40 (b. g. n. p. u. w) \\
\hline Q6P050 & F-box and leucine-rich protein 22 (a. m. n. u) \\
\hline F8WF38 & Gamma-aminobutyric acid type B receptor subunit 1 (a. b. g. h. s. u. w) \\
\hline Q9H4A5 & Golgi phosphoprotein 3-like (a. b. c. g. n. u) \\
\hline P16520 & Guanine nucleotide-binding protein $G(I) / G(S) / G(T)$ subunit beta-3 $3^{\text {(a. b. g. n. o. s. u) }}$ \\
\hline U3KQKO & Histone H2B ((b. m. p. u. w) \\
\hline P33778 & Histone H2B type 1-B (b. m. p. u. w) \\
\hline P62807 & Histone $\mathrm{H} 2 \mathrm{~B}$ type $1-C / E / F / G / I^{\text {(b. i. j. p. u. w) }}$ \\
\hline
\end{tabular}




\begin{tabular}{|c|c|}
\hline P58876 & Histone H2B type 1-D (b. m. p. u. w) \\
\hline Q93079 & Histone $\mathrm{H} 2 \mathrm{~B}$ type $1-\mathrm{H}^{\text {(b. m. p. u. w) }}$ \\
\hline P06899 & Histone H2B type 1-J (b. I. j.p. u. w) \\
\hline 060814 & Histone H2B type 1-K (b. I. j. p. u. w) \\
\hline Q99880 & Histone H2B type 1-L (b. m. p. u. w) \\
\hline Q99879 & Histone H2B type 1-M (b. m. p. u. w) \\
\hline Q99877 & Histone H2B type 1-N (b. m. p. u. w) \\
\hline P23527 & Histone H2B type 1-O (b. m. p. u. w) \\
\hline Q16778 & Histone H2B type 2-E ${ }^{\text {(b. i. .j. p. u. w) }}$ \\
\hline Q5QNW6 & Histone H2B type 2-F (b. m. p. u. w) \\
\hline Q8N257 & Histone H2B type 3-B (b. m. p. u. w) \\
\hline P57053 & Histone H2B type F-S (b. I. j.p. u. w) \\
\hline P01859 & Ig gamma-2 chain C region (b. e. j. o. u. w) \\
\hline P01860 & Ig gamma-3 chain C region (b. e. j. o. u. w) \\
\hline P01861 & Ig gamma-4 chain C region (b. e. j. o. u. w) \\
\hline Q9NZM3 & Intersectin-2 (a. b. g. I. n. u. w) \\
\hline K7ERE3 & Keratin. type I cytoskeletal $13^{\text {(d. m. o. p. q. u) }}$ \\
\hline Q92615 & La-related protein 4B ${ }^{\text {(b. g. n. u) }}$ \\
\hline
\end{tabular}




\begin{tabular}{|c|c|c|}
\hline & COJIRO & Mitotic spindle assembly checkpoint protein MAD1 (Fragment) (a.b. g. n. p. u. x) \\
\hline & I3LOM3 & MYC-associated zinc finger protein (Purine-binding transcription factor). isoform CRA_e $\mathrm{e}^{\text {(b. m.t. u) }}$ \\
\hline & P80188 & Neutrophil gelatinase-associated lipocalin (c.j. o. u) \\
\hline & 015031 & Plexin-B2 (b. g. o. s. u) \\
\hline & Q8NHV4 & Protein NEDD1 ${ }^{\text {(b. g. n. u) }}$ \\
\hline & K7EPI1 & Queuine tRNA-ribosyltransferase (Fragment) ${ }^{\text {(a. b. e. g. n. s. u) }}$ \\
\hline & 043361 & Zinc finger protein $749^{\text {(b. m. p. u) }}$ \\
\hline \multirow[t]{11}{*}{ pH 1_2 hours } & Accession name & Protein name and Classification \\
\hline & P54619 & 5'-AMP-activated protein kinase subunit gamma-1 ${ }^{\text {(a. b. . . . . o. p. s.u) }}$ \\
\hline & HOYDN9 & ADP-ribosylation factor GTPase-activating protein 2 (Fragment) ${ }^{\text {(m. t. u) }}$ \\
\hline & Q9NVJ2 & ADP-ribosylation factor-like protein $8 B^{\text {(a. b. c. . . . . m. s. w) }}$ \\
\hline & C9JV77 & Alpha-2-HS-glycoprotein (a. b. g. m. o.u) \\
\hline & Q8WXJ9 & Ankyrin repeat and SOCS box protein $17^{\text {(a. b. m. r. u) }}$ \\
\hline & F8W696 & Apolipoprotein A-I (a.c. g. o. u) \\
\hline & F8WCU9 & AT-rich interactive domain-containing protein $2^{\text {(b. m. p.s.u) }}$ \\
\hline & Q8NAA4 & Autophagy-related protein $16-2^{\text {(m.t. u) }}$ \\
\hline & A6NG92 & CCDC144A protein (b. m.t. x) \\
\hline & Q00610 & Clathrin heavy chain $1^{\text {(f. g. n. s. u. v. v. w) }}$ \\
\hline
\end{tabular}


A0A087WVQ6

A2RUR9

Q3MJ40

E9PLP0

060269

P19526

E5RJS3

P07098

Q14789

Q8IZP7

P01777

AOAOG2JMZ3

C9JPF8

Q9H9H5

I3L170

P10636

Q9Y618

Q6ZVD8
Clathrin heavy chain (b.g. s. u)

Coiled-coil domain-containing protein 144A ${ }^{\text {(b. m.t. } x)}$

Coiled-coil domain-containing protein 144B ${ }^{\text {(b. m. t. u) }}$

Cysteine--tRNA ligase. cytoplasmic (b. c. g. n. u. w)

G protein-regulated inducer of neurite outgrowth $2^{\text {(b. g.t. u) }}$

Galactoside 2-alpha-L-fucosyltransferase 1 (a. b. g. r. u)

Gamma-aminobutyric acid receptor subunit alpha-1 (Fragment) (a. c. g. s. u)

Gastric triacylglycerol lipase (a. b. g. n. r. u)

Golgin subfamily B member $1^{\text {(d. m. s. u) }}$

Heparan-sulfate 6-O-sulfotransferase 3 (a. b. g. s. u)

Ig heavy chain V-III region TEI (b. e. j. o.x)

Leukocyte immunoglobulin-like receptor subfamily B member 3 (f. I. j. s. u. w)

MAP6 domain containing 1. isoform CRA_b (d. m. n. x)

MAP6 domain-containing protein $1^{\text {(b. d. g. n. u) }}$

Microtubule-associated protein (m. n.x)

Microtubule-associated protein tau (f.g.n.u.w)

Nuclear receptor corepressor $2^{\text {(a.g.p.u) }}$

$\mathrm{PH}$ domain leucine-rich repeat-containing protein phosphatase $2^{{ }^{(b .} \text { m. n. p. u) }}$ 


\begin{tabular}{|c|c|}
\hline Q9BUL5 & PHD finger protein $23^{\text {(b. g. n. p. u. } x)}$ \\
\hline P00558 & Phosphoglycerate kinase 1 (a. b. g. h. n. o. s. u) \\
\hline Q9HAU0 & Pleckstrin homology domain-containing family A member 5 (b. g. n. s. u. x) \\
\hline A0JP02 & PLEKHA5 protein (b. g. n. p. s.u) \\
\hline 000180 & Potassium channel subfamily $\mathrm{K}$ member $1^{\text {(a. b. c. g. n. s. u. x) }}$ \\
\hline Н3ВТН7 & Protein ADGRG1 (Fragment) ${ }^{\text {(f. m. s. u. x) }}$ \\
\hline A0A087WW89 & Protein IGHV3-72 (m.t.x) \\
\hline Q5T7Y6 & Protein S100 (b. I. t. u.v) \\
\hline P23297 & Protein S100-A1 (a. b. g. n. u.v.w) \\
\hline Q9UPX0 & Protein turtle homolog B (b. g. s. u) \\
\hline Q8IYA2 & Putative coiled-coil domain-containing protein $144 C^{(\text {b. m. t. u) }}$ \\
\hline HOY9A8 & Rho-related BTB domain-containing protein 3 (Fragment) (a. b. g. n. u) \\
\hline 096013 & Serine/threonine-protein kinase PAK 4 (f. h. n. u. w) \\
\hline Q16650 & T-box brain protein $1^{\text {(b. m. p. u. w) }}$ \\
\hline Q5T1B5 & Type I inositol 1.4.5-trisphosphate 5-phosphatase (b. g. m. o. s. u. w) \\
\hline 094966 & Ubiquitin carboxyl-terminal hydrolase 19 (b. g. n. u. w) \\
\hline Q14157 & Ubiquitin-associated protein 2-like (b. m.t. u.w) \\
\hline P49459 & Ubiquitin-conjugating enzyme E2 A ${ }^{\text {(a. b. m. n. p. w) }}$ \\
\hline
\end{tabular}




\section{Q8N7F7 \\ Ubiquitin-like protein 4B (b. m. n.w) \\ A0A087WSY3 \\ Uncharacterized protein ${ }^{(b . m . n . w)}$ \\ Q9UM54 \\ Unconventional myosin-VI (a.b.d. g. n. p.s.u) \\ P08670 \\ Vimentin (b.j. n. u. w) \\ Q14584 \\ Zinc finger protein $266^{\text {(b.m.p.u) }}$ \\ Q969W8 \\ Zinc finger protein $566^{\text {(b. m. p. u) }}$}

Proteins were classified according to: General Function: ${ }^{\text {a) }}$ metabolism; ${ }^{\text {b) }}$ biological process; ${ }^{\mathrm{c})}$ transport; ${ }^{\mathrm{d})}$ structure and structural organization; ${ }^{\mathrm{e})}$ information pathways;

f) miscellanea; Function in AEP: g) metabolism; ${ }^{\text {h) }}$ tissue regeneration; ${ }^{\text {i) }}$ antimicrobial; j) immune response; ${ }^{k)}$ lubrication; ${ }^{1)}$ biomineralization; ${ }^{\text {m) }}$ unknown biological function; Origin: ${ }^{\text {n) }}$ cytoplasm origin; ${ }^{\circ)}$ extracellular origin; ${ }^{\text {p) }}$ nucleus origin; ${ }^{\text {q) }}$ cytoskeleton origin; ${ }^{\text {r) }}$ intracellular origin; ${ }^{\text {s) }}$ membrane origin; ${ }^{\text {t) }}$ unknown protein origin; Interaction: ${ }^{\mathrm{u})}$ protein/protein interaction; ${ }^{\mathrm{v})}$ calcium/phosphate binding; ${ }^{\mathrm{w})}$ other molecular interaction; ${ }^{\mathrm{x})}$ unknown molecular interaction 
Table 2. Classification and relative quantification of proteins identified in the acquired enamel pellicle collected after different times of formation (3 minutes or 2 hours) and treatments (Water, $\mathrm{HCl} \mathrm{pH} 2$ or $\mathrm{HCl} \mathrm{pH} \mathrm{1).}$

\begin{tabular}{|c|c|c|c|}
\hline Accession number & Protein name & Ratio Water-2h / Water-3min & $P$ \\
\hline P63261 & Actin. cytoplasmic $2^{(a, d, g, j, n, q, u, w)}$ & 2.70 & 1.00 \\
\hline P59666 & Neutrophil defensin $3^{(b, i, j, o, u)}$ & 2.70 & 1.00 \\
\hline P60709 & Actin. cytoplasmic $1(b, m, n, q, u, w)$ & 2.63 & 1.00 \\
\hline P59665 & Neutrophil defensin $1^{(b, i, j, o, u)}$ & 1.85 & 0.99 \\
\hline P01037 & Cystatin-SN (a, b, g, o, u) & 0.77 & 0.03 \\
\hline Accession number & Protein name & Ratio $\mathrm{pH} 2-2 \mathrm{~h} / \mathrm{pH} 2-3 \mathrm{~min}$ & $\boldsymbol{P}$ \\
\hline P02768 & Serum albumin $(a, b, g, h, o, u, w)$ & 1.58 & 1.00 \\
\hline P02808 & Statherin $(b, l, o, u, v)$ & 0.79 & 0.00 \\
\hline P01877 & Ig alpha-2 chain $C$ region $(b, e, l, j, o, u)$ & 0.45 & 0.00 \\
\hline P01876 & Ig alpha-1 chain $C$ region $(b, e, l, j, o, u)$ & 0.44 & 0.00 \\
\hline Accession number & Protein name & Ratio pH1-2h/ pH1-3min & $P$ \\
\hline P02768 & Serum albumin $(a, b, g, h, o, u, w)$ & 2.44 & 1.00 \\
\hline P02808 & Statherin $(b, l, o, u, v)$ & 2.32 & 1.00 \\
\hline P01876 & Ig alpha- 1 chain $C$ region $(b, e, l, j, o, u)$ & 1.18 & 1.00 \\
\hline P01877 & Ig alpha-2 chain $C$ region $(b, e, 1, j, o, u)$ & 1.16 & 0.99 \\
\hline
\end{tabular}




\begin{tabular}{|c|c|c|c|}
\hline Accession number & Protein name & Ratio $\mathrm{pH} 2-3 \mathrm{~min} /$ Water-3min & $P$ \\
\hline P02808 & Statherin $(b, l, o, u, v)$ & 0.48 & 0.00 \\
\hline Accession number & Protein name & Ratio $\mathrm{pH} 2-2 \mathrm{~h} /$ Water-2h & $P$ \\
\hline P05109 & Protein S100-A8 ${ }^{(b, i, j, n, o, p, q, u, w)}$ & 1.20 & 0.98 \\
\hline P05164 & Myeloperoxidase $(\mathrm{a}, \mathrm{b}, \mathrm{g}, \mathrm{j}, \mathrm{r}, \mathrm{u})$ & 0.75 & 0.00 \\
\hline P02788 & Lactotransferrin $(b, c, i, j, n, o, p, u, w)$ & 0.74 & 0.00 \\
\hline P15515 & Histatin-1 $(b, 1,1,0, u)$ & 0.65 & 0.00 \\
\hline P59666 & Neutrophil defensin $3^{(b, i, j, o, u)}$ & 0.58 & 0.00 \\
\hline P01877 & Ig alpha-2 chain $\mathrm{C}$ region $(\mathrm{b}, \mathrm{e}, \mathrm{l}, \mathrm{j}, \mathrm{o}, \mathrm{u})$ & 0.51 & 0.00 \\
\hline P01876 & Ig alpha-1 chain $\mathrm{C}$ region $(\mathrm{b}, \mathrm{e}, \mathrm{l}, \mathrm{j}, \mathrm{o}, \mathrm{u})$ & 0.48 & 0.00 \\
\hline P02808 & Statherin $(b, l, o, u, v)$ & 0.38 & 0.00 \\
\hline P61626 & Lysozyme $C^{(a, b, i, o, u)}$ & 0.30 & 0.00 \\
\hline Accession number & Protein name & Ratio pH1-3min/Water-3min & $P$ \\
\hline P02808 & Statherin $(b, I, o, u, v)$ & 0.44 & 0.00 \\
\hline
\end{tabular}




\begin{tabular}{|c|c|c|c|}
\hline P02768 & Serum albumin $(a, b, g, h, o, u, w)$ & 0.36 & 0.00 \\
\hline Accession number & Protein name & Ratio pH1-2h/Water-2h & $P$ \\
\hline P02768 & Serum albumin $(a, b, g, h, o, u, w)$ & 2.1 & 1.0 \\
\hline C9JKR2 & Albumin. isoform CRA_k ${ }^{(c, m, o, u)}$ & 2.0 & 1.0 \\
\hline P02787 & Serotransferrin $(e, d, h, i, m, o, u, w)$ & 2.0 & 1.0 \\
\hline P02538 & Keratin. type II cytoskeletal $6 A^{(d, h, o, p, s, u)}$ & 1.8 & 1.0 \\
\hline P48668 & Keratin. type II cytoskeletal $6 \mathrm{C}(\mathrm{d}, \mathrm{m}, \mathrm{o}, \mathrm{u})$ & 1.8 & 1.0 \\
\hline P04259 & Keratin. type II cytoskeletal 6B $(\mathrm{d}, \mathrm{m}, \mathrm{o}, \mathrm{u})$ & 1.7 & 1.0 \\
\hline P01876 & Ig alpha-1 chain $\mathrm{C}$ region $(\mathrm{b}, \mathrm{e}, \mathrm{l}, \mathrm{j}, \mathrm{o}, \mathrm{u})$ & 1.3 & 1.0 \\
\hline P01877 & Ig alpha-2 chain $\mathrm{C}$ region ${ }^{(b, e, l, j, o, u)}$ & 1.3 & 1.0 \\
\hline P62736 & Actin aortic smooth muscle $(b, m, n, q, u, w)$ & 0.88 & 0.04 \\
\hline P63261 & Actin. cytoplasmic $2^{(a, d, g, j, n, q, u, w)}$ & 0.86 & 0.00 \\
\hline P68032 & Actin. alpha cardiac muscle $1^{(b, m, n, q, u, w)}$ & 0.85 & 0.02 \\
\hline P60709 & Actin. cytoplasmic $1^{(b, m, n, q, u, w)}$ & 0.85 & 0.00 \\
\hline P0CG38 & POTE ankyrin domain family member $I^{(b, m, o, u)}$ & 0.84 & 0.04 \\
\hline P63267 & Actin. gamma-enteric smooth muscle $(b, m, n, q, u, w)$ & 0.84 & 0.02 \\
\hline P68133 & Actin. alpha skeletal muscle $(b, m, n, q, u, w)$ & 0.84 & 0.02 \\
\hline Q6S8J3 & POTE ankyrin domain family member $E^{(b, m, o, u)}$ & 0.84 & 0.01 \\
\hline
\end{tabular}




\begin{tabular}{|c|c|c|c|}
\hline A5A3E0 & POTE ankyrin domain family member $F(b, m, o, u)$ & 0.84 & 0.01 \\
\hline P02788 & Lactotransferrin $(b, c, i, j, n, o, p, u, w)$ & 0.64 & 0.00 \\
\hline P59665 & Neutrophil defensin $1^{(b, i, j, o, u)}$ & 0.51 & 0.00 \\
\hline P59666 & Neutrophil defensin $3^{(b, i, j, o, u)}$ & 0.49 & 0.00 \\
\hline P61626 & Lysozyme $C^{(a, b, i, o, u)}$ & 0.42 & 0.00 \\
\hline Accession number & Protein name & Ratio pH1-3min /pH2-3min & $\boldsymbol{P}$ \\
\hline P02768 & Serum albumin $(\mathrm{a}, \mathrm{b}, \mathrm{g}, \mathrm{h}, \mathrm{o}, \mathrm{u}, \mathrm{w})$ & 1.43 & 0.97 \\
\hline Accession number & Protein name & Ratio pH1-2h/ pH2-2h & $P$ \\
\hline P01876 & Ig alpha-1 chain C region ${ }^{(b, e, l, j, 0, u)}$ & 2.78 & 1.00 \\
\hline P02808 & Statherin $(b, l, o, u, v)$ & 2.78 & 1.00 \\
\hline P01877 & Ig alpha-2 chain $\mathrm{C}$ region ${ }^{(\mathrm{b}, \mathrm{e}, \mathrm{l}, \mathrm{j}, \mathrm{o}, \mathrm{u})}$ & 2.56 & 1.00 \\
\hline P02768 & Serum albumin $(a, b, g, h, o, u, w)$ & 2.17 & 1.00 \\
\hline C9JKR2 & Albumin. isoform CRA_k $(c, m, o, u$ & 2.08 & 1.00 \\
\hline P01037 & Cystatin-SN $(\mathrm{a}, \mathrm{b}, \mathrm{g}, \mathrm{o}, \mathrm{u})$ & 2.08 & 1.00 \\
\hline P04259 & Keratin. type II cytoskeletal 6B $(\mathrm{d}, \mathrm{m}, \mathrm{o}, \mathrm{u})$ & 1.75 & 1.00 \\
\hline P48668 & Keratin. type II cytoskeletal $6 \mathrm{C}(\mathrm{d}, \mathrm{m}, \mathrm{o}, \mathrm{u})$ & 1.75 & 1.00 \\
\hline P02538 & Keratin. type II cytoskeletal 6A $(d, h, o, p, s, u)$ & 1.72 & 1.00 \\
\hline P61626 & $C(a, b, i, o u)$ & 1.43 & 1.00 \\
\hline
\end{tabular}




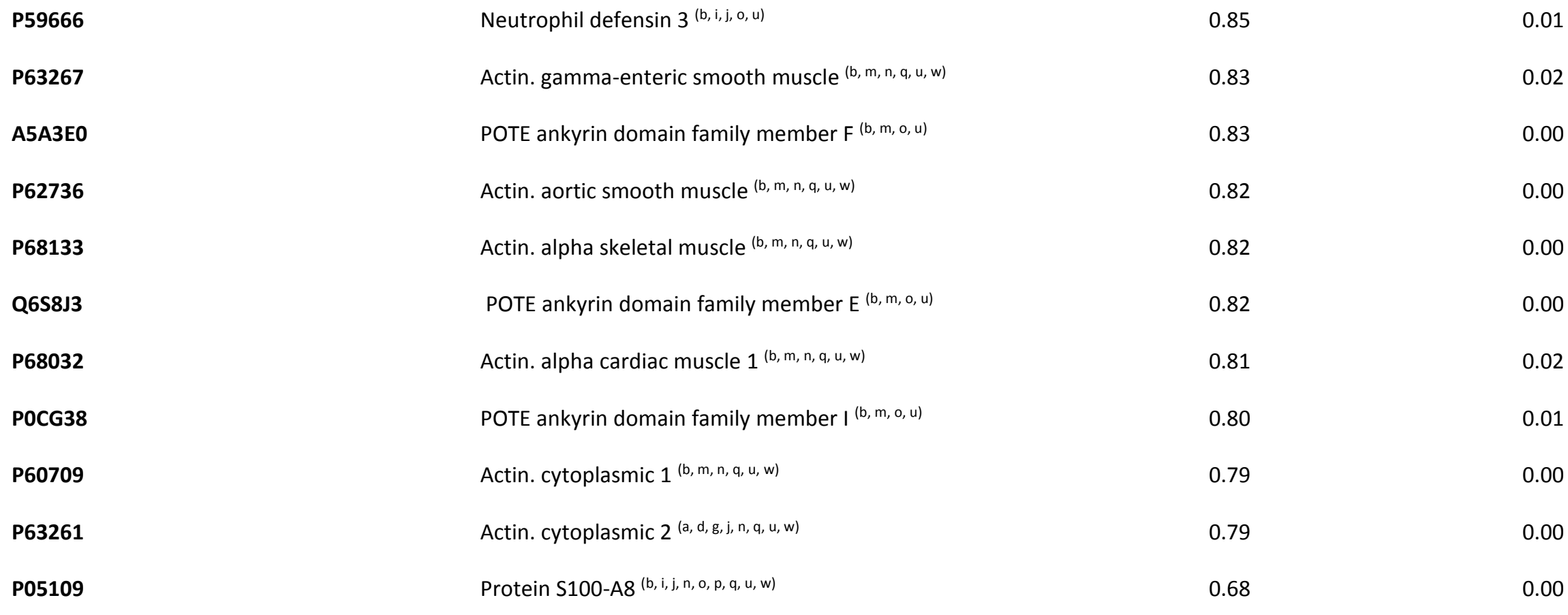

Proteins were classified according to: General Function: ${ }^{\text {a) }}$ metabolism; b) biological process; ${ }^{\text {c) }}$ transport; ${ }^{\text {d) }}$ structure and structural organization; e) information pathways; ${ }^{\text {f) }}$ miscellanea; Function in AEP: ${ }^{g}$ ) metabolism; ${ }^{\text {h) }}$ tissue regeneration; ${ }^{\text {i) }}$ antimicrobial; ${ }^{\text {j) }}$ immune response; ${ }^{\mathrm{k})}$ lubrication; ${ }^{\text {l) }}$ biomineralization; ${ }^{\text {m) }}$ unknown biological function; Origin: ${ }^{\text {n) }}$ cytoplasm origin; ${ }^{o)}$ extracellular origin; ${ }^{p)}$ nucleus origin; ${ }^{\text {q) }}$ cytoskeleton origin; ${ }^{\text {r) }}$ intracellular origin; ${ }^{\text {s) }}$ membrane origin; ${ }^{\text {t) }}$ unknown protein origin; Interaction: ${ }^{u)}$ protein/protein interaction; v) calcium/phosphate binding; ${ }^{\text {w) }}$ other molecular interaction; ${ }^{\mathrm{x})}$ unknown molecular interaction. 
Table S1. Classification of the identified proteins in the acquired enamel pellicle collected after different times of formation and treatments 3 minutes ou 2 hours, water or hydrochloric acid $\mathrm{pH} 1$ or hydrochloric acid $\mathrm{pH} 2$.

\begin{tabular}{|c|c|c|c|c|c|c|c|}
\hline Accession & Description & $\begin{array}{l}\text { Water } \\
3 \text { min }\end{array}$ & $\begin{array}{c}\text { Water } 2 \\
\text { Hours }\end{array}$ & $\begin{array}{c}\text { pH } 2 \text { / } \\
\text { 3min }\end{array}$ & $\begin{array}{c}\text { pH } 2 \text { / } 2 \\
\text { Hours }\end{array}$ & $\begin{array}{c}\text { pH } 1 \text { / } 2 \\
\text { Hours }\end{array}$ & $\begin{array}{l}\text { pH 1/ } \\
\text { 3min }\end{array}$ \\
\hline P54619 & 5'-AMP-activated protein kinase subunit gamma-1 ${ }^{(\mathrm{a}, \mathrm{b}, \mathrm{g}, \mathrm{n}, \mathrm{o}, \mathrm{p}, \mathrm{s}, \mathrm{u})}$ & & & & & Yes & \\
\hline Q8TE56 & A disintegrin and metalloproteinase with thrombospondin motifs $17^{(\mathrm{b}, \mathrm{m}, \mathrm{o}, \mathrm{u})}$ & & & & Yes & & \\
\hline P22303 & Acetylcholinesterase ${ }^{(\mathrm{a}, \mathrm{e}, \mathrm{g}, \mathrm{o}, \mathrm{s}, \mathrm{u}, \mathrm{n})}$ & & Yes & & & & \\
\hline P68032 & Actin, alpha cardiac muscle $1^{(\mathrm{b}, \mathrm{m}, \mathrm{n}, \mathrm{q}, \mathrm{u}, \mathrm{w})}$ & & Yes & & Yes & Yes & \\
\hline P68133 & Actin, alpha skeletal muscle ${ }^{(b, m, n, q, u, w)}$ & & Yes & & Yes & Yes & \\
\hline P62736 & Actin, aortic smooth muscle ${ }^{(b, m, n, q, u, w)}$ & & Yes & & Yes & Yes & \\
\hline P60709 & Actin, cytoplasmic $1^{(\mathrm{b}, \mathrm{m}, \mathrm{n}, \mathrm{q}, \mathrm{u}, \mathrm{w})}$ & Yes & Yes & & Yes & Yes & \\
\hline P63261 & Actin, cytoplasmic $2^{(\mathrm{a}, \mathrm{d}, \mathrm{g}, \mathrm{j}, \mathrm{n}, \mathrm{q}, \mathrm{u}, \mathrm{w})}$ & Yes & Yes & & Yes & Yes & \\
\hline P63267 & Actin, gamma-enteric smooth muscle ${ }^{(b, m, n, q, u, w)}$ & & Yes & & Yes & Yes & \\
\hline HOYDN9 & ADP-ribosylation factor GTPase-activating protein 2 (Fragment) ${ }^{(\mathrm{m}, \mathrm{t}, \mathrm{x})}$ & & & & & Yes & \\
\hline Q9NVJ2 & ADP-ribosylation factor-like protein $8 \mathrm{~B}^{(\mathrm{a}, \mathrm{b}, \mathrm{c}, \mathrm{g}, \mathrm{n}, \mathrm{m}, \mathrm{s}, \mathrm{w})}$ & & & & & Yes & \\
\hline C9JKR2 & Albumin, isoform CRA_k $(\mathrm{c}, \mathrm{m}, \mathrm{o}, \mathrm{u})$ & Yes & Yes & & Yes & Yes & \\
\hline C9JV77 & Alpha-2-HS-glycoprotein ${ }^{(a, b, g, m, o, u)}$ & & & & & Yes & \\
\hline Q5T085 & Alpha-amylase (Fragment) ${ }^{(\mathrm{a}, \mathrm{g}, \mathrm{t}, \mathrm{u})}$ & & & & Yes & & \\
\hline P04745 & Alpha-amylase $1^{(\mathrm{a}, \mathrm{g}, \mathrm{o}, \mathrm{u})}$ & & & & Yes & & \\
\hline
\end{tabular}




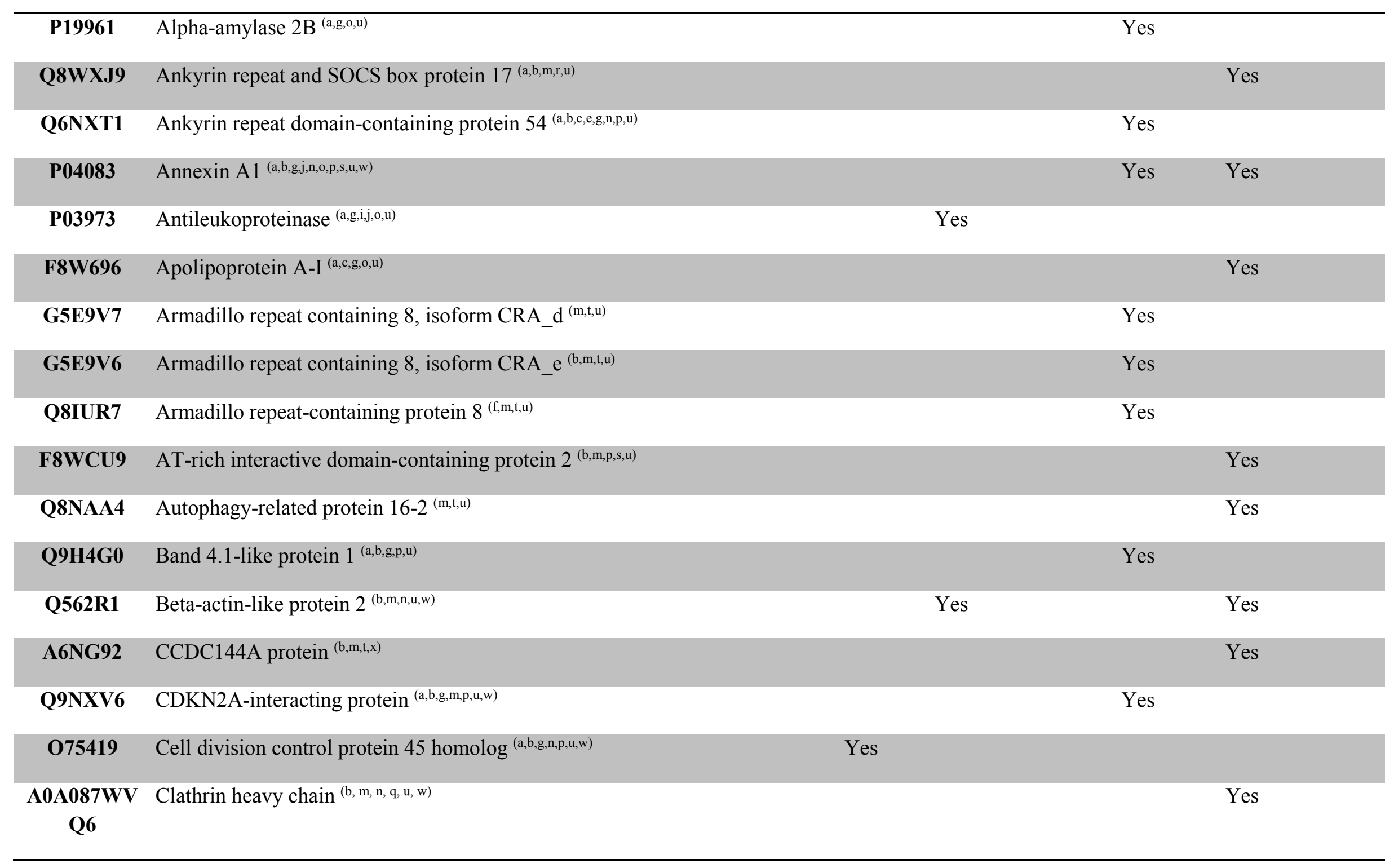




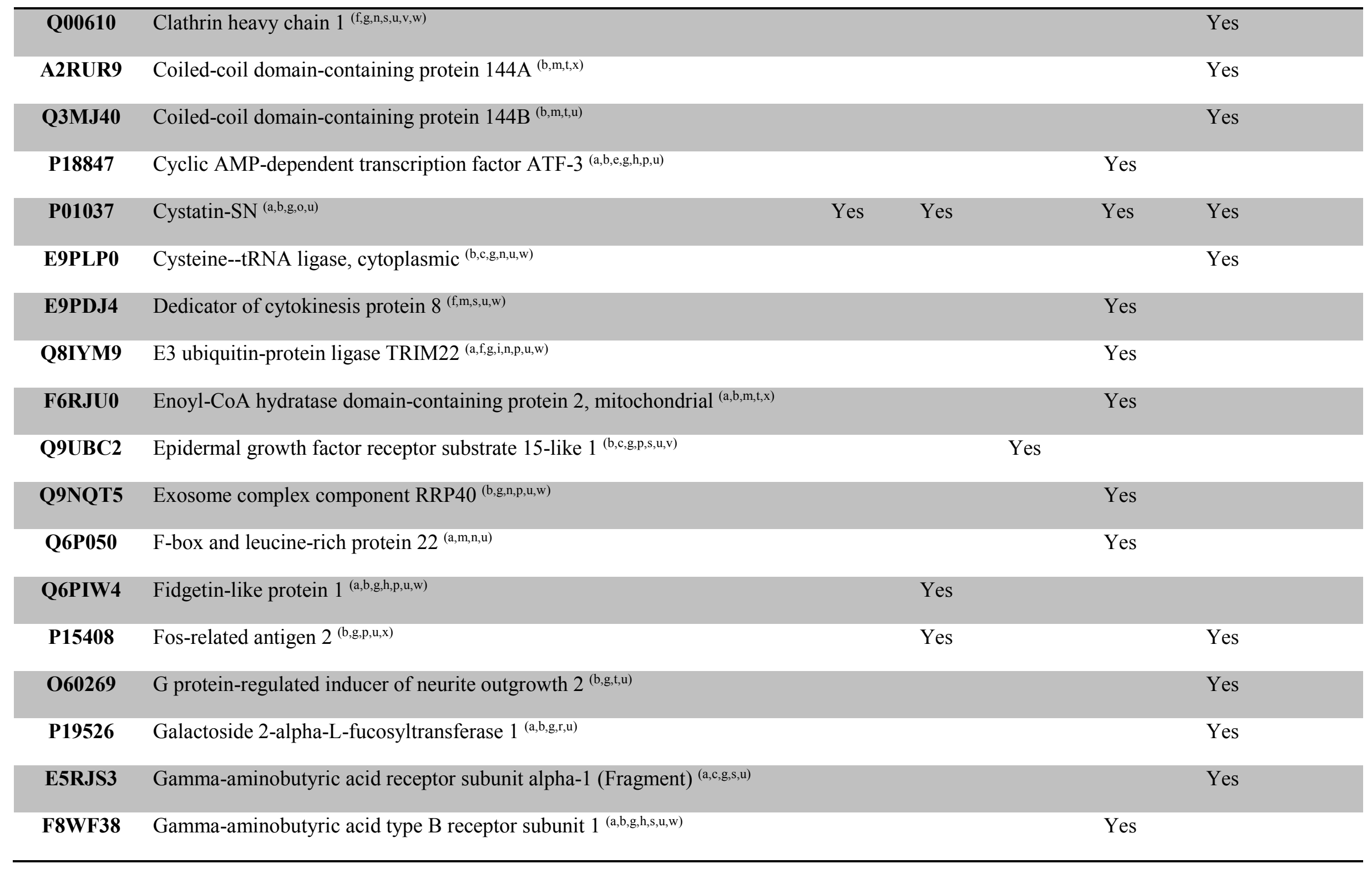




\begin{tabular}{|c|c|c|}
\hline P07098 & Gastric triacylglycerol lipase ${ }^{(a, b, g, n, r, u)}$ & Yes \\
\hline Q9H4A5 & Golgi phosphoprotein 3-like ${ }^{(\mathrm{a}, \mathrm{b}, \mathrm{c}, \mathrm{g}, \mathrm{n}, \mathrm{u})}$ & Yes \\
\hline Q14789 & Golgin subfamily B member $1^{(\mathrm{d}, \mathrm{m}, \mathrm{s}, \mathrm{u})}$ & Yes \\
\hline P16520 & Guanine nucleotide-binding protein $\mathrm{G}(\mathrm{I}) / \mathrm{G}(\mathrm{S}) / \mathrm{G}(\mathrm{T})$ subunit beta-3 ${ }^{(\mathrm{a}, \mathrm{b}, \mathrm{g}, \mathrm{n}, \mathrm{o}, \mathrm{s}, \mathrm{u})}$ & Yes \\
\hline P00738 & Haptoglobin $(\mathrm{a}, \mathrm{b}, \mathrm{g}, \mathrm{i}, \mathrm{j}, \mathrm{o}, \mathrm{u}, \mathrm{w})$ & Yes \\
\hline P04792 & Heat shock protein beta-1 $(\mathrm{b}, \mathrm{d}, \mathrm{m}, \mathrm{n}, \mathrm{p}, \mathrm{q}, \mathrm{u}, \mathrm{w})$ & \\
\hline Q8IZP7 & Heparan-sulfate 6-O-sulfotransferase $3^{(\mathrm{a}, \mathrm{b}, \mathrm{g}, \mathrm{p}, \mathrm{u})}$ & Yes \\
\hline P15515 & Histatin-1 ${ }^{(b, i, 1, o, u)}$ & Yes \\
\hline H7BXF5 & Histone deacetylase complex subunit SAP130 ${ }^{(a, b, g, p, u)}$ & \\
\hline U3KQK0 & Histone $\mathrm{H} 2 \mathrm{~B}^{(\mathrm{b}, \mathrm{m}, \mathrm{p}, \mathrm{u}, \mathrm{w})}$ & Yes \\
\hline P33778 & Histone H2B type $1-\mathrm{B}^{(\mathrm{b}, \mathrm{m}, \mathrm{p}, \mathrm{u}, \mathrm{w})}$ & Yes \\
\hline P62807 & Histone $\mathrm{H} 2 \mathrm{~B}$ type $1-\mathrm{C} / \mathrm{E} / \mathrm{F} / \mathrm{G} / \mathrm{I}^{(\mathrm{b}, \mathrm{i}, \mathrm{j}, \mathrm{p}, \mathrm{u}, \mathrm{w})}$ & Yes \\
\hline P58876 & Histone H2B type 1-D ${ }^{(b, m, p, u, w)}$ & Yes \\
\hline Q93079 & Histone $\mathrm{H} 2 \mathrm{~B}$ type $1-\mathrm{H}^{(\mathrm{b}, \mathrm{i}, \mathrm{j}, \mathrm{p}, \mathrm{u}, \mathrm{w})}$ & Yes \\
\hline P06899 & Histone H2B type 1-J (b,i,j,p,u,w) & Yes \\
\hline 060814 & Histone $\mathrm{H} 2 \mathrm{~B}$ type $1-\mathrm{K}^{(\mathrm{b}, \mathrm{I}, \mathrm{j}, \mathrm{p}, \mathrm{u}, \mathrm{w})}$ & Yes \\
\hline Q99880 & Histone H2B type 1-L ${ }^{(b, m, p, u, w)}$ & Yes \\
\hline Q99879 & Histone H2B type 1-M ${ }^{(b, m, p, u)}$ & Yes \\
\hline
\end{tabular}




\begin{tabular}{|c|c|c|c|c|c|c|c|}
\hline Q99877 & Histone H2B type 1-N ${ }^{(b, I, j, p, u, u, w)}$ & & & & Yes & & \\
\hline $\mathbf{P 2 3 5 2 7}$ & Histone $\mathrm{H} 2 \mathrm{~B}$ type $1-\mathrm{O}^{(\mathrm{b}, \mathrm{I}, \mathrm{j}, \mathrm{p}, \mathrm{u}, \mathrm{w})}$ & & & & Yes & & \\
\hline Q16778 & Histone H2B type 2-E ${ }^{(b, \mathrm{i}, \mathrm{j}, \mathrm{p}, \mathrm{u}, \mathrm{w})}$ & & & & Yes & & \\
\hline Q5QNW6 & Histone $\mathrm{H} 2 \mathrm{~B}$ type $2-\mathrm{F}^{(\mathrm{b}, \mathrm{m}, \mathrm{p}, \mathrm{u}, \mathrm{w})}$ & & & & Yes & & \\
\hline Q8N257 & Histone H2B type 3-B ${ }^{(b, m, p, u, w)}$ & & & & Yes & & \\
\hline P31276 & Homeobox protein Hox-C13 (b,e,g,p,u) & & Yes & & & & \\
\hline P01876 & Ig alpha-1 chain $\mathrm{C}$ region ${ }^{(\mathrm{b}, \mathrm{e}, \mathrm{I}, \mathrm{j}, \mathrm{o}, \mathrm{u})}$ & Yes & Yes & Yes & Yes & Yes & Yes \\
\hline P01877 & Ig alpha-2 chain $\mathrm{C}$ region ${ }^{(\mathrm{b}, \mathrm{e}, \mathrm{I}, \mathrm{j}, \mathrm{o}, \mathrm{u})}$ & Yes & Yes & Yes & Yes & Yes & Yes \\
\hline P01859 & Ig gamma-2 chain $\mathrm{C}$ region ${ }^{(\mathrm{b}, \mathrm{e}, \mathrm{j}, \mathrm{o}, \mathrm{u}, \mathrm{w})}$ & & & & Yes & & \\
\hline P01766 & Ig heavy chain V-III region $\mathrm{BRO}^{(\mathrm{b}, \mathrm{j}, \mathrm{o}, \mathrm{x})}$ & & Yes & & & Yes & \\
\hline P01777 & Ig heavy chain V-III region TEI ${ }^{(b, e, j, 0, x)}$ & & & & & Yes & \\
\hline Q5TA45 & Integrator complex subunit $11^{(\mathrm{b}, \mathrm{e}, \mathrm{g}, \mathrm{n}, \mathrm{p}, \mathrm{u})}$ & & Yes & & & & \\
\hline 043187 & Interleukin-1 receptor-associated kinase-like $2^{(\mathrm{b}, \mathrm{g}, \mathrm{j}, \mathrm{n}, \mathrm{p}, \mathrm{s}, \mathrm{u})}$ & Yes & & & & & \\
\hline Q5JVA3 & Interleukin-15 receptor subunit alpha (Fragment) ${ }^{(\mathrm{b}, \mathrm{e}, \mathrm{h}, \mathrm{j}, \mathrm{p}, \mathrm{u})}$ & & Yes & & & & \\
\hline Q9NZM3 & Intersectin-2 ${ }^{(\mathrm{a}, \mathrm{b}, \mathrm{g}, \mathrm{l}, \mathrm{n}, \mathrm{u}, \mathrm{w})}$ & & & & Yes & & \\
\hline
\end{tabular}




\begin{tabular}{|c|c|c|c|c|c|}
\hline P13646 & Keratin, type I cytoskeletal $13^{(\mathrm{d}, \mathrm{m}, \mathrm{o}, \mathrm{p}, \mathrm{q}, \mathrm{u})}$ & & & Yes & \\
\hline F8W0C6 & Keratin, type II cytoskeletal 5 (Fragment) ${ }^{(\mathrm{d}, \mathrm{h}, \mathrm{o}, \mathrm{p}, \mathrm{s}, \mathrm{w})}$ & & Yes & & \\
\hline P02538 & Keratin, type II cytoskeletal $6 \mathrm{~A}^{(\mathrm{ad}, \mathrm{h}, \mathrm{o}, \mathrm{p}, \mathrm{s}, \mathrm{u})}$ & & Yes & Yes & Yes \\
\hline P04259 & Keratin, type II cytoskeletal 6B ${ }^{(\mathrm{d}, \mathrm{m}, \mathrm{o}, \mathrm{u})}$ & & Yes & Yes & Yes \\
\hline Q9NSK0 & Kinesin light chain $4^{(\mathrm{a}, \mathrm{c}, \mathrm{g}, \mathrm{n}, \mathrm{u})}$ & & Yes & & \\
\hline Q8WV93 & Lactation elevated protein $1^{(\mathrm{a}, \mathrm{g}, \mathrm{n}, \mathrm{u})}$ & & Yes & & \\
\hline $\mathbf{P 0 2 7 8 8}$ & Lactotransferrin ${ }^{(b, c, i, j, n, o, p, u, w)}$ & & Yes & Yes & Yes \\
\hline Q92615 & La-related protein 4B ${ }^{(b, g, n, u)}$ & & & Yes & \\
\hline P61626 & Lysozyme $\mathrm{C}^{(\mathrm{a}, \mathrm{b}, \mathrm{i}, \mathrm{o}, \mathrm{u})}$ & & Yes & Yes & Yes \\
\hline C9JPF8 & MAP6 domain containing 1 , isoform CRA_b (d,m,n,x) & & & & Yes \\
\hline Q9H9H5 & MAP6 domain-containing protein $1^{(b, d, g, n, u)}$ & & & & Yes \\
\hline P08493 & Matrix Gla protein $(\mathrm{b}, \mathrm{m}, \mathrm{o}, \mathrm{u})$ & Yes & Yes & & \\
\hline I3L170 & Microtubule-associated protein ${ }^{(\mathrm{m}, \mathrm{n}, \mathrm{x})}$ & & & & Yes \\
\hline P10636 & Microtubule-associated protein tau ${ }^{(\mathrm{f}, \mathrm{g}, \mathrm{n}, \mathrm{u}, \mathrm{w})}$ & & & & Yes \\
\hline
\end{tabular}




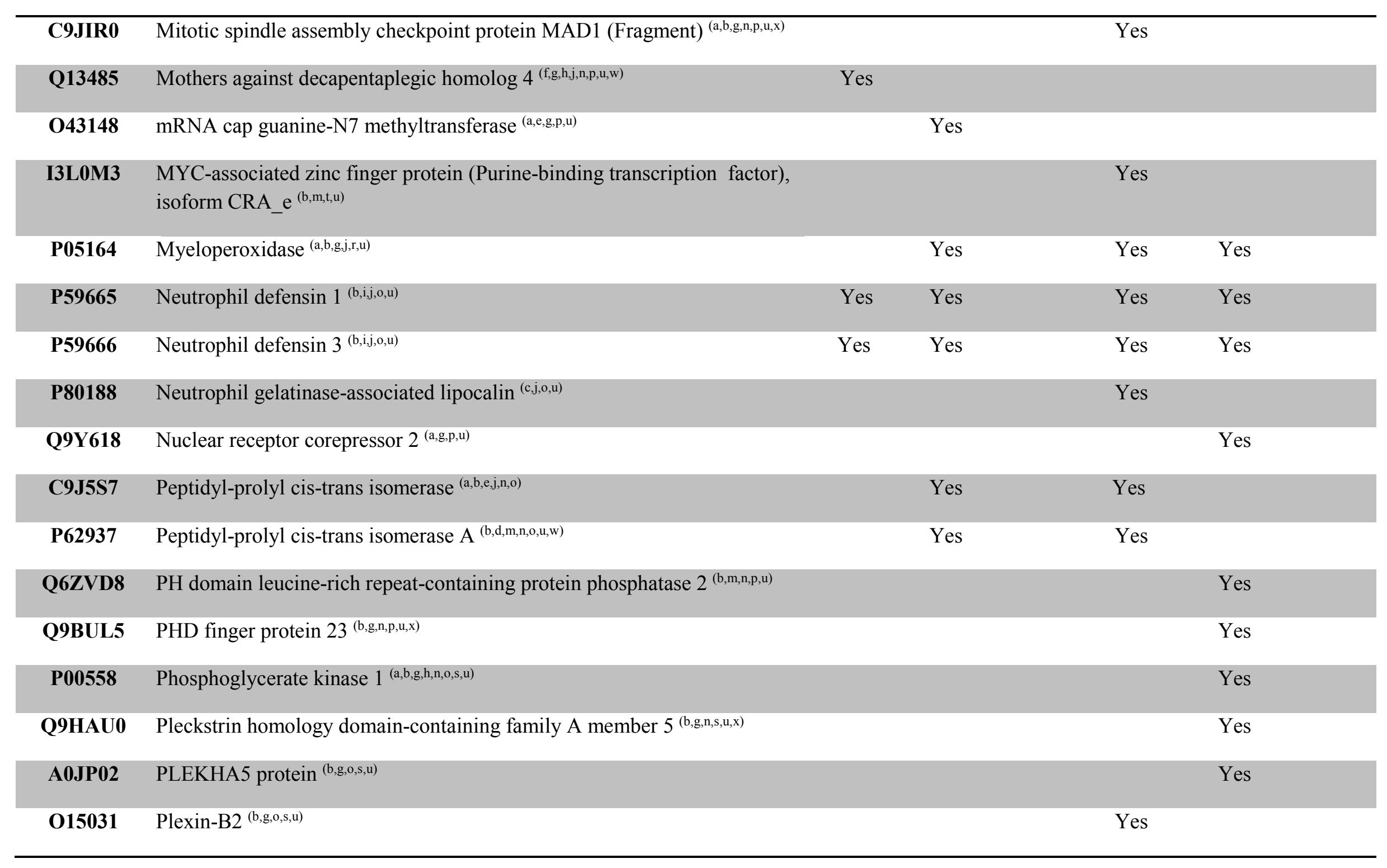




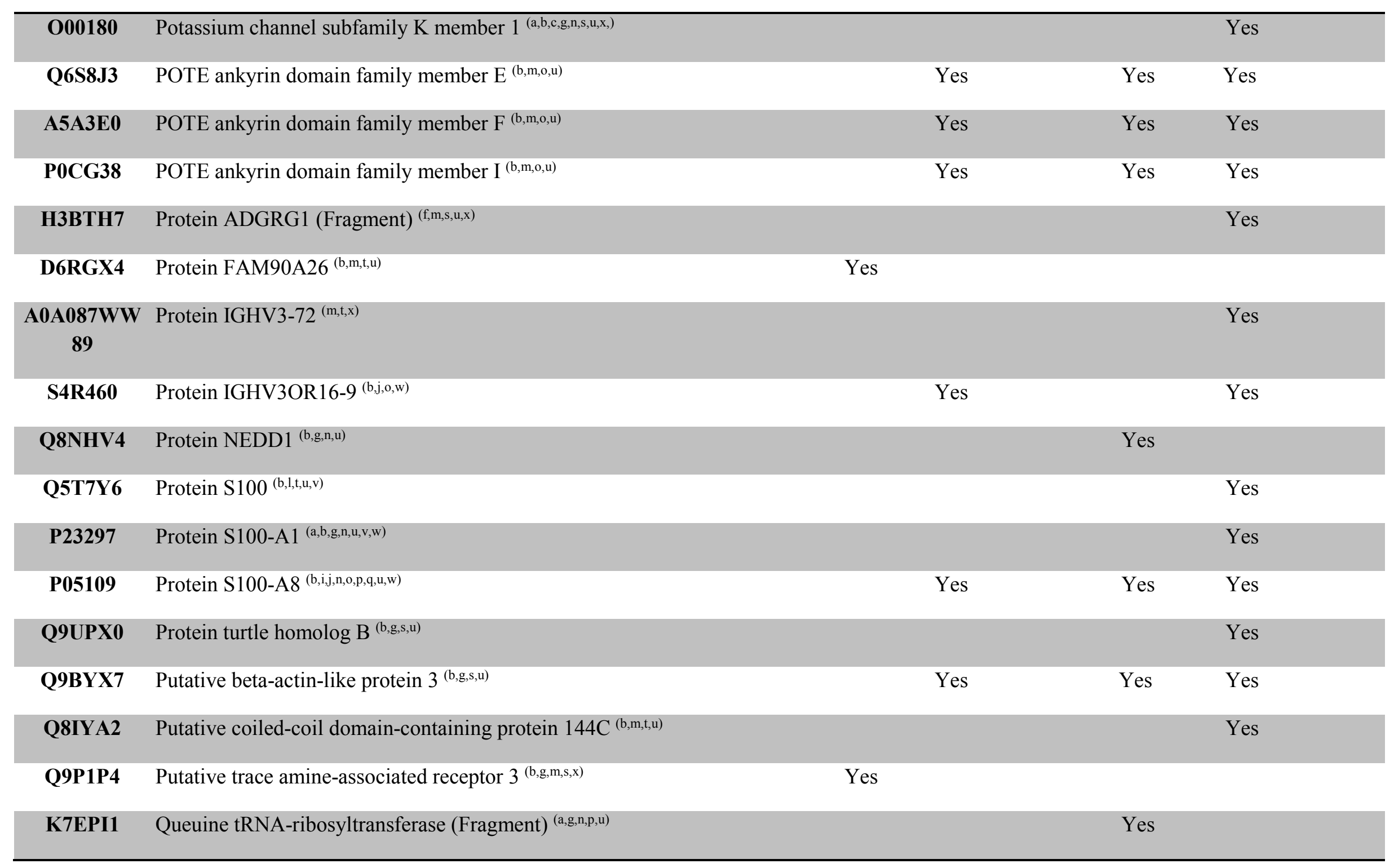




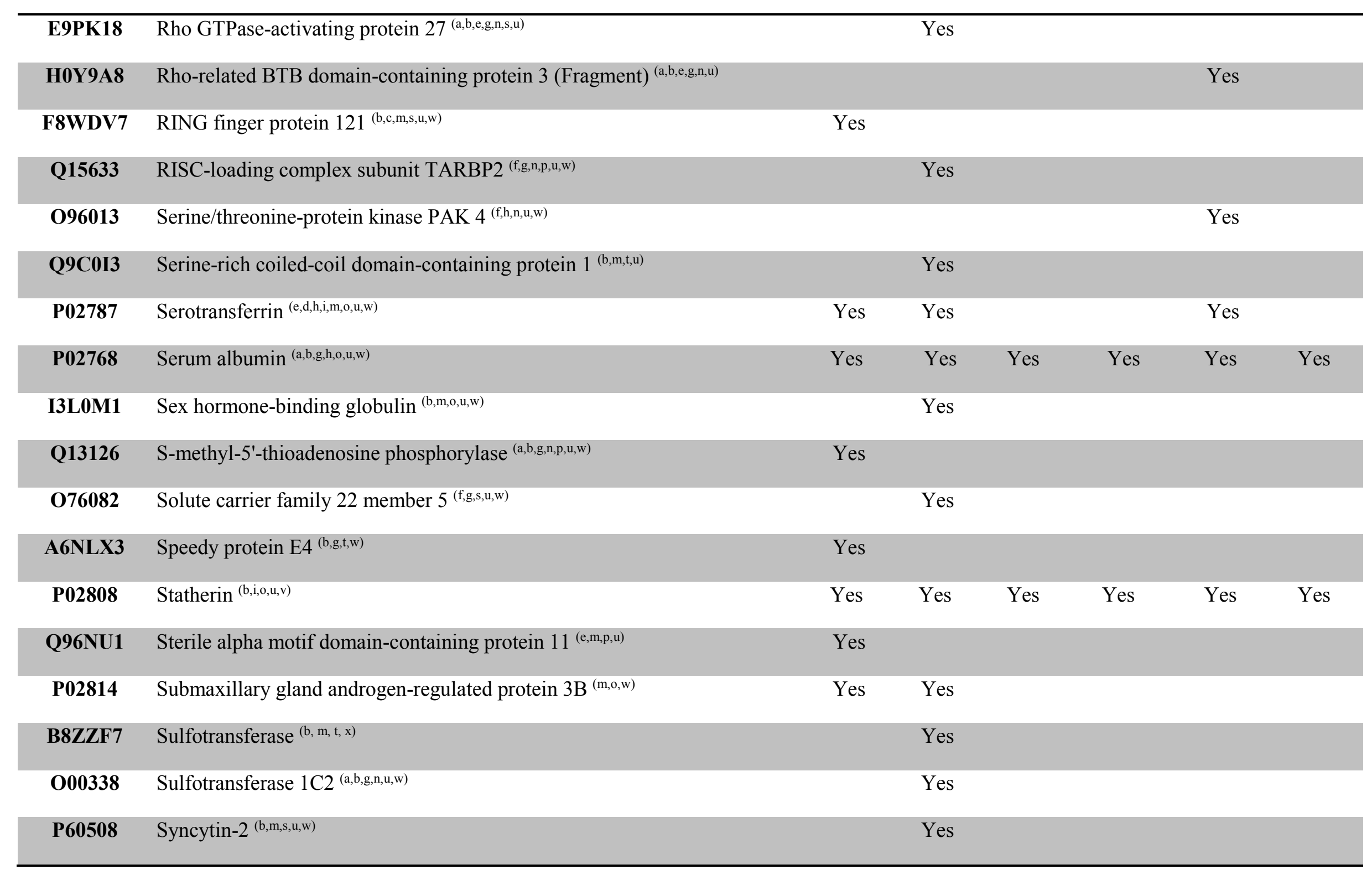




\begin{tabular}{|c|c|c|c|}
\hline Q7Z7G0 & Target of Nesh-SH3 ${ }^{(\mathrm{b}, \mathrm{d}, \mathrm{m}, \mathrm{o}, \mathrm{u}, \mathrm{w})}$ & Yes & \\
\hline Q16650 & T-box brain protein $1^{(\mathrm{b}, \mathrm{m}, \mathrm{p}, \mathrm{u}, \mathrm{w})}$ & & Yes \\
\hline Q12799 & T-complex protein 10A homolog $(\mathrm{b}, \mathrm{m}, \mathrm{n}, \mathrm{u})$ & Yes & \\
\hline Q9NNW7 & Thioredoxin reductase 2 , mitochondrial ${ }^{(a, b, g, n, u, w)}$ & Yes & \\
\hline X6REB3 & Transcription factor E2-alpha ${ }^{(\mathrm{f}, \mathrm{g}, \mathrm{p}, \mathrm{u}, \mathrm{w})}$ & Yes & \\
\hline P07437 & Tubulin beta chain ${ }^{(b, \mathrm{~d}, \mathrm{~m}, \mathrm{n}, \mathrm{g}, \mathrm{u}, \mathrm{w})}$ & Yes & \\
\hline Q13885 & Tubulin beta-2A chain ${ }^{(\mathrm{b}, \mathrm{d}, \mathrm{m}, \mathrm{n}, \mathrm{q}, \mathrm{u}, \mathrm{w})}$ & Yes & \\
\hline Q9BVA1 & Tubulin beta-2B chain ${ }^{(b, d, m, n, q, u, w)}$ & Yes & \\
\hline P04350 & Tubulin beta-4A chain ${ }^{(\mathrm{b}, \mathrm{d}, \mathrm{m}, \mathrm{n}, \mathrm{q}, \mathrm{u}, \mathrm{w})}$ & Yes & \\
\hline P68371 & Tubulin beta-4B chain ${ }^{(b, d, m, n, q, u, w)}$ & Yes & \\
\hline Q5T1B5 & Type I inositol 1,4,5-trisphosphate 5-phosphatase ${ }^{(\mathrm{b}, \mathrm{g}, \mathrm{m}, \mathrm{o}, \mathrm{s}, \mathrm{u}, \mathrm{w})}$ & & Yes \\
\hline 094966 & Ubiquitin carboxyl-terminal hydrolase $19^{(\mathrm{b}, \mathrm{g}, \mathrm{n}, \mathrm{u}, \mathrm{w})}$ & & Yes \\
\hline Q14157 & Ubiquitin-associated protein 2-like ${ }^{(\mathrm{b}, \mathrm{m}, \mathrm{t}, \mathrm{u}, \mathrm{w})}$ & & Yes \\
\hline P49459 & Ubiquitin-conjugating enzyme E2 A ${ }^{(a, b, m, t, u, w)}$ & & Yes \\
\hline Q8N7F7 & Ubiquitin-like protein $4 \mathrm{~B}^{(\mathrm{b}, \mathrm{m}, \mathrm{n}, \mathrm{w})}$ & & Yes \\
\hline F2Z2F3 & Uncharacterized protein ${ }^{(b, m, n, w)}$ & Yes & \\
\hline $\begin{array}{c}\text { A0A087WSY } \\
3\end{array}$ & Uncharacterized protein ${ }^{(\mathrm{b}, \mathrm{m}, \mathrm{t}, \mathrm{x})}$ & & Yes \\
\hline
\end{tabular}




\begin{tabular}{|c|c|c|c|}
\hline Q96КН6 & Uncharacterized protein C18orf12 ${ }^{(\mathrm{b}, \mathrm{m}, \mathrm{t}, \mathrm{w})}$ & Yes & \\
\hline Q9UM54 & Unconventional myosin-VI ${ }^{(\mathrm{a}, \mathrm{b}, \mathrm{d}, \mathrm{g}, \mathrm{n}, \mathrm{p}, \mathrm{s}, \mathrm{u}, \mathrm{u})}$ & & Yes \\
\hline P08670 & Vimentin $(\mathrm{b}, \mathrm{j}, \mathrm{n}, \mathrm{u}, \mathrm{w})$ & & Yes \\
\hline F8W0F8 & Voltage-dependent L-type calcium channel subunit beta-3 ${ }^{(\mathrm{f}, \mathrm{g}, \mathrm{n}, \mathrm{s}, \mathrm{v}, \mathrm{u})}$ & Yes & \\
\hline Q14584 & Zinc finger protein $266^{(b, m, p, u)}$ & & Yes \\
\hline Q969W8 & Zinc finger protein $566^{(b, m, p, u)}$ & & Yes \\
\hline 043361 & Zinc finger protein $749^{(b, m, p, u)}$ & & Yes \\
\hline P25311 & Zinc-alpha-2-glycoprotein ${ }^{(\mathrm{a}, \mathrm{b}, \mathrm{g}, \mathrm{o}, \mathrm{u}, \mathrm{w})}$ & Yes & \\
\hline
\end{tabular}

Proteins were classified according to: General Function: ${ }^{a)}$ metabolism; ${ }^{b)}$ biological process; ${ }^{c)}$ transport; ${ }^{d)}$ structure and structural organization; ${ }^{\text {e) }}$ information pathways; ${ }^{\text {f) }}$ miscellanea; Function in AEP: ${ }^{\text {g) }}$ metabolism; ${ }^{\text {h) }}$ tissue regeneration; ${ }^{\text {i) }}$ antimicrobial; ${ }^{\mathrm{j})}$ immune response; ${ }^{\mathrm{k})}$ lubrication; ${ }^{\mathrm{l}}$ biomineralization; ${ }^{\mathrm{m})}$ unknown biological function; Origin: ${ }^{\text {n) }}$ cytoplasm origin; ${ }^{\text {o) }}$ extracellular origin; ${ }^{\text {p) }}$ nucleus origin; ${ }^{\text {q) }}$ cytoskeleton origin; ${ }^{\text {r) }}$ intracellular origin; ${ }^{\text {s) }}$ membrane origin; ${ }^{\text {t) }}$ unknown protein origin; Interaction: ${ }^{\text {u) }}$ protein/protein interaction; v) calcium/phosphate binding; ${ }^{\text {w) }}$ other molecular interaction; ${ }^{\mathrm{x})}$ unknown molecular interaction. 





\section{DISCUSSION}

We employed a different protocol according to a recently developed methodology to extract and prepare the acquired enamel pellicle proteins for analyses, and this protocol was choose, since that increased the number of identified proteins, and this fact was verify in another study (VENTURA et al., 2017).

The main objective of this study was, collect Acquired pellicles and identify proteins that are not removal after challenges with $\mathrm{HCl}$. Hydrochloric acid was choose due to is an intrinsic acid, with a low $\mathrm{pH}$, the $\mathrm{HCl}$ reaches the oral cavity through regurgitation, vomiting, bulimia, anorexia nervosa and gatroesophageal reflux (MOAZZEZ; BARTLETT, 2014). Therefore, the lesions of dental erosion have been commonly found in patients with these diseases (MEURMAN et al., 1994). With all this knowledge, the identification of these acids-resistant proteins is very important, since they have a great potential to protect the teeth against intrinsic erosion.

Since it has been reported, no significantly differences in the protector potential against demineralization by acids, in pellicles formed in three minutes or 120 minutes formation (HANNIG, M. et al., 2004) the second aim of this present study was evaluate changes in the protein profile of the AEP along its time of formation, under normal conditions and after acids challenges with $\mathrm{HCl}$.

In the identify, most of the proteins were found in the groups with 2 hours of formation, so we can conclude that the number of proteins increase along the time of formation, which is expected and has been reported in a previous study (LEE et al., 2013). Analyzing the results of this study, an interesting finding was that only quite few number of proteins were find in the groups with 3 minutes of formation after exposure to $\mathrm{HCl}$, which is Serum albumin, Statherin and immunoglobulins, and it is possible that these proteins are responsible for most of the protection conferred by the short-term pellicle.

There is some proteins that are only identify in the groups of 2 hours of formation, like Myeloperoxidase, Lysozyme C, Protein S-100-A8, Lactotransferrin and isoforms of keratin, this finding instigate that these proteins probably do not bind to hydroxyapatite, but bind to another proteins, like the precursor proteins. 
This protocol allowed the identification of 180 proteins. From these four proteins are important and should be detach, because this four were in all the groups, even in the short time of formation, regardless of the treatment received. Serum albumin is one of this proteins they are present in all groups, this protein originary from plasma and its capable to bind ions as calcium (HEMINGWAY et al., 2008)(HEMINGWAY et al., 2008). This fact can be important for protection against acids, since that ovalbumin was verify in another study and was able to reduce the dissolution of hydroxyapatite by acids challenges in vitro (HEMINGWAY et al., 2008; KOSORIC; HECTOR; ANDERSON, 2010). Another protein is Statherin, a 43-residue phosphorylated protein typical found in saliva, with primary sequence likeness to osteopontin and casein that was able to bind hydroxyapatite and calcium. For the interaction with hydroxyapatite are important the helical conformation at the $\mathrm{N}$-terminus and the negative charge (RAJ et al., 1992). This interaction apparent to be powerful, since not even exposed to $\mathrm{HCl}$ $(0,1 \mathrm{M})$ was able to separate and detach this protein from the teeth surface. In fact solid-state nuclear magnetic resonance (NMR) studies confirmed that the $\mathrm{N}$-terminus of Statherin strongly binds to hydroxyapatite, while the middle and C-terminal regions are dynamic and flexible (NAGANAGOWDA; GURURAJA; LEVINE). In order to protect against loss mineral teeth, it is prompting that statherin-like peptides containing at least $15 \mathrm{~N}$-terminal residues or more, are needed (SHAH et al., 2011). It was recently found in studies that concentration of calcium from acquired pellicle collected in patients with dental erosion it is $50 \%$ reduced, while the concentration of Statherin is $35 \%$ reduced, showing that erosion and this protein is related (CARPENTER et al., 2014). These results suggested that these 2 proteins are resistant to removal by an intrinsic acid, and potential candidates to be more studied, and included in products to aim helps patients with dental erosion.

About the time formation of AEP, it should be emphasize that possible protective proteins, such as Serum albumin increased along time of formation, even after application of $\mathrm{HCl}$ (both for $\mathrm{HCl} \mathrm{pH1}$ and $\mathrm{HCl} \mathrm{pH}$ 2) and this also happens to Statherin (for $\mathrm{HCl} \mathrm{pH} \mathrm{1).} \mathrm{As} \mathrm{mentioned} \mathrm{above,} \mathrm{one} \mathrm{study} \mathrm{did} \mathrm{not} \mathrm{find} \mathrm{any} \mathrm{difference} \mathrm{in} \mathrm{the}$ protection of AEP formed in 3 minutes or 120 minutes. It must be taken into account this study was designed in situ, while the present study was conducted in vivo, and the results obtained here are more close to reality, than those described in studies in vitro (MASSON et al., 2013; SIQUEIRA et al., 2012) or in situ (DELECRODE et al., 2015) protocols. Another different point it is, an in situ study was employed orange juice as 
erosive solution, mimicking intrinsic erosions. For this study the acid had the lower $\mathrm{pH}$ $(\mathrm{HCl} \mathrm{pH} 1.0$ or 2.0), compared to the study with orange juice $(\mathrm{pH} 2.5$. It is possible that for the AEP exposure to the intrinsic acid, time of maturation is important for the protection against lost mineral by intrinsic desmineralization. In agreement of this assumption, an in situ study showed that contact to the dental surface to saliva for 30 minutes for AEP formation, provided less enamel resistance to $\mathrm{HCl}$ erosive attack than the contact to saliva for 2 hours (MENDONCA et al., 2017). Proposing that more mature pellicles might promoted better protection against erosion by intrinsic acid, than short-term pellicle.

Prepossessing, a great number of proteins was identify, like uniquely in one of the groups, for the groups exposed by $\mathrm{HCl}$ after 2 hours of formation. (approximately 50 proteins for each of these groups). Suggesting that many proteins are resistant to $\mathrm{HCl}$, and remain, even at low $\mathrm{pH}$.

Concluding, the present study identify Serum albumin and Statherin as potentially protective protein and these proteins are resistant and remain after $\mathrm{HCl}$ exposure, even in the pellicles formed in short time (3min). Moreover, was observed that are many proteins in the mature pellicles, and these proteins are more resistant to removal by an intrinsic acid, even at $\mathrm{pH} 1$. This point to there is an increased in the power of protection against intrinsic acids along the time of pellicle formation, which is necessary to gain further knowledge and be evaluated in future studies. 





\section{REFERENCES}

BARBOUR, M. E.; LUSSI, A. Erosion in relation to nutrition and the environment. Monogr Oral Sci, v. 25, p. 143-54, 2014.

BUZALAF, M. A.; HANNAS, A. R.; KATO, M. T. Saliva and dental erosion. J Appl Oral Sci, v. 20, n. 5, p. 493-502, Sep-Oct 2012.

CARPENTER, G. et al. Composition of enamel pellicle from dental erosion patients. Caries Res, v. 48, n. 5, p. 361-7, 2014.

DELECRODE, T. R. et al. Exposure to acids changes the proteomic of acquired dentine pellicle. J Dent, v. 43, n. 5, p. 583-8, May 2015.

DENT, J. et al. Epidemiology of gastro-oesophageal reflux disease: a systematic review. Gut, v. 54 , n. 5 , p. $710-7$, May 2005.

ERICSON, T. et al. Ellipsometric studies of film formation on tooth enamel and hydrophilic silicon surfaces. Acta Odontol Scand, v. 40, n. 4, p. 197-201, 1982.

HANNIG, C. et al. The effect of acidic beverages on the ultrastructure of the acquired pellicle-an in situ study. Arch Oral Biol, v. 54, n. 6, p. 518-26, Jun 2009.

HANNIG, C. et al. Erosive effects of different acids on bovine enamel: release of calcium and phosphate in vitro. Arch Oral Biol, v. 50, n. 6, p. 541-52, Jun 2005.

HANNIG, C.; HANNIG, M.; ATTIN, T. Enzymes in the acquired enamel pellicle. Eur J Oral Sci, v. 113, n. 1, p. 2-13, Feb 2005.

HANNIG, M.; BALZ, M. Influence of in vivo formed salivary pellicle on enamel erosion. Caries Res, v. 33, n. 5, p. 372-9, Sep-Oct 1999.

HANNIG, M.; BALZ, M. Protective properties of salivary pellicles from two different intraoral sites on enamel erosion. Caries Res, v. 35, n. 2, p. 142-8, Mar-Apr 2001.

HANNIG, M. et al. Protective effect of the in situ formed short-term salivary pellicle. Arch Oral Biol, v. 49, n. 11, p. 903-10, Nov 2004.

HANNIG, M. et al. Influence of salivary pellicle formation time on enamel demineralization-an in situ pilot study. Clin Oral Investig, v. 7, n. 3, p. 158-61, Sep 2003. 
HANNIG, M.; JOINER, A. The structure, function and properties of the acquired pellicle. Monogr Oral Sci, v. 19, p. 29-64, 2006.

HELLWIG, E.; LUSSI, A. Oral hygiene products, medications and drugs - hidden aetiological factors for dental erosion. Monogr Oral Sci, v. 25, p. 155-62, 2014.

HEMINGWAY, C. A. et al. Inhibition of hydroxyapatite dissolution by ovalbumin as a function of $\mathrm{pH}$, calcium concentration, protein concentration and acid type. Caries Res, v. 42, n. 5, p. 348-53, 2008.

KOSORIC, J.; HECTOR, M. P.; ANDERSON, P. The influence of proteins on demineralization kinetics of hydroxyapatite aggregates. J Biomed Mater Res A, v. 94, n. 3, p. 972-7, Sep 01 2010.

LEE, Y. H. et al. Proteomic evaluation of acquired enamel pellicle during in vivo formation. PLoS One, v. 8, n. 7, p. e67919, 2013.

LENDENMANN, U.; GROGAN, J.; OPPENHEIM, F. G. Saliva and dental pellicle--a review. Adv Dent Res, v. 14, p. 22-8, Dec 2000.

LUSSI, A. et al. Dental erosion--an overview with emphasis on chemical and histopathological aspects. Caries Res, v. 45 Suppl 1, p. 2-12, 2011.

MAGALHAES, A. C. et al. Insights into preventive measures for dental erosion. J Appl Oral Sci, v. 17, n. 2, p. 75-86, Mar-Apr 2009.

MASSON, N. et al. Acidulated Phosphate Fluoride Application Changes the Protein Composition of Human Acquired Enamel Pellicle. Caries Research, v. 47, n. 3, p. 251-258, 2013.

MENDONCA, F. L. et al. In situ effect of enamel salivary exposure time and type of intraoral appliance before an erosive challenge. Clin Oral Investig, Jan 072017.

MEURMAN, J. $\mathrm{H}$. et al. Oral and dental manifestations in gastroesophageal reflux disease. Oral Surg Oral Med Oral Pathol, v. 78, n. 5, p. 583-9, Nov 1994.

MOAZZEZ, R.; ANGGIANSAH, A.; BARTLETT, D. W. The association of acidic reflux above the upper oesophageal sphincter with palatal tooth wear. Caries Res, v. 39, n. 6, p. 475-8, Nov-Dec 2005.

MOAZZEZ, R.; BARTLETT, D. Intrinsic causes of erosion. Monogr Oral Sci, v. 25, p. 180-96, 2014. 
assignment and structure-function correlations. J Biomol Struct Dyn, v. 16, n. 1, p. 91-107, Aug 1998.

RAJ, P. A. et al. Salivary statherin. Dependence on sequence, charge, hydrogen bonding potency, and helical conformation for adsorption to hydroxyapatite and inhibition of mineralization. J Biol Chem, v. 267, n. 9, p. 5968-76, Mar 251992.

SHAH, S. et al. An in vitro scanning microradiography study of the reduction in hydroxyapatite demineralization rate by statherin-like peptides as a function of increasing $\mathrm{N}$-terminal length. Eur J Oral Sci, v. 119 Suppl 1, p. 13-8, Dec 2011.

SHELLIS, R. P.; FEATHERSTONE, J. D.; LUSSI, A. Understanding the chemistry of dental erosion. Monogr Oral Sci, v. 25, p. 163-79, 2014.

SIQUEIRA, W. L.; CUSTODIO, W.; MCDONALD, E. E. New insights into the composition and functions of the acquired enamel pellicle. J Dent Res., v. 91, n. 12, p. 1110-8, Dec 2012.

VENTURA, T. M. S. et al. The proteomic profile of the acquired enamel pellicle changes according to its location in the dental arches. Archives of Oral Biology, v. 79, p. 20-29, 2017.

VUKOSAVLJEVIC, D. et al. Acquired pellicle as a modulator for dental erosion. Arch Oral Biol, v. 59, n. 6, p. 631-8, Jun 2014.

WETTON, S. et al. Exposure time of enamel and dentine to saliva for protection against erosion: a study in vitro. Caries Res, v. 40, n. 3, p. 213-7, 2006.

WIEGAND, A. et al. Impact of the in situ formed salivary pellicle on enamel and dentine erosion induced by different acids. Acta Odontol Scand, v. 66, n. 4, p. 225-30, Aug 2008. 





\section{ANNEX 1}

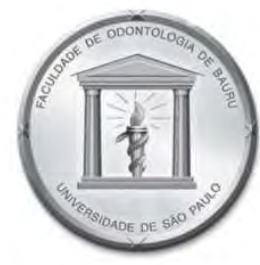

\section{Universidade de São Paulo Faculdade de Odontologia de Bauru}

Departamento de Ciências Biológicas

Disciplina de Bioquímica

TERMO DE CONSENTIMENTO LIVRE E ESCLARECIDO

Convido você estudante da pós graduação desta faculdade a participar como voluntário no trabalho experimental intitulado "Determinação de mudanças na composição da película adquirida do esmalte formada in vivo após exposição a ácido clorídrico: estudo proteômico." Você deverá comparecer ao laboratório de Bioquímica da Faculdade de Odontologia de Bauru - USP, no dia e horário que será estabelecido pelo pesquisador que entrará em contato com você no dia anterior de cada etapa da coleta de película adquirida, totalizando 12 dias que serão necessários a sua presença.

O objetivo deste trabalho será verificar se haverá alteraçoes na película adquirida, após exposição ao ácido clorídrico, mimetizando pessoas que sofrem de doenças gastresofágicas como refluxos, bulimia etc. Será também verificado, quais das proteínas presentes na película adquirida, teve resistência a tal exposição ao ácido e se futuramente ela poderá exercer papel protetor aos dentes contra processos erosivos.

A película adquirida é uma fina camada transparente formada sobre os dentes assim que eles começam a aparecer na boca e entram em contato com a saliva. É sobre essa camada que se forma a placa dentária, ou seja, os restos de alimentos se grudam.

Assim, se o(a) Sr.(a) concordar a participar do projeto, para sua participação você terá que vir a Faculdade de Odontologia de Bauru - FOB para duas etapas, uma etapa será para a coleta de película após 3 minutos de formação e em outra etapa será para a coleta de película após 2 horas de formação, sendo que, para cada etapa, serão 6 dias, totalizando 12 dias consecutivos, tendo início sempre às 8 horas da manhã. Estas etapas serão realizadas em dias distintos. Você receberá uma meticulosa profilaxia dentária com pedra pomes, para que a película adquirida (camada de proteínas originárias da saliva que se ligam à superfície do dente) se forme naturalmente sobre o esmalte dentário. Depois de 3 minutos ou 2 horas após a formação da película adquirida, será aplicado $50 \mu \mathrm{L}$ de ácido Clorídrico $(0,1 \mathrm{~mol}, \mathrm{pH} 1)$, $50 \mu \mathrm{L}$ de ácido Clorídrico $(0,01 \mathrm{~mol} \mathrm{pH} 2)$ ou água durante apenas 10 segundos (não causando nenhum dano ao esmalte do seu dente), dependendo da fase da pesquisa em que você estiver. A película será removida com um papel de filtro umedecido em ácido cítrico a 3\%. Durante este período, você não poderá consumir alimentos ou bebidas. Todas as amostras coletadas serão depois de feita a análise, serão descartadas de forma adequada no laboratório de bioquímica da Faculdade de Odontologia - FOB.

Este projeto traz como benefícios á importância o conhecimento sobre quais proteínas da película adquirida do esmalte são resistentes à remoção por ácido clorídrico que irá nos permitir elaborar novas estratégias preventivas para proteção contra a erosão dentária intrínseca. Em estudos futuros poder-se-á empregar procedimentos de "engenharia" de película adquirida, levando à formação de uma película com composição tal, que possa proteger o tecido dentário contra desafios erosivos intrínsecos em pacientes susceptíveis.

Quanto aos benefícios oferecidos a você, no início do estudo será feito um exame clínico em relação às suas condições bucais e o resultado deste exame será prontamente informado a você. Caso seja detectado algum problema, faremos o encaminhamento à triagem da $\mathrm{FOB}$, e você será atendido conforme agendamento. Além disto, no final do estudo, serāo dadas instruçōes sobre higiene bucal, por escrito e verbalmente. A participação será voluntária e entende-se que você poderá fazer qualquer pergunta sobre os procedimentos, sendo que será livre para desistir de participar a qualquer momento, sem nenhum prejuízo de sua parte. Em adição, você terá, também, por parte dos pesquisadores, a garantia do sigilo que assegura a sua privacidade.

Destacamos ainda que não há risco nenhum à sua saúde com a participação nesta pesquisa, já que os tratamentos com o ácido serão de pequena duração assim sendo não ocorrerão prejuízo algum aos voluntários da pesquisa.

Os gastos que forem gerados por este trabalho ficarão a cargo da responsável pelo projeto. Importante ressaltar que não está sendo considerado nenhum pagamento ou recompensa material pela participação do sujeito neste estudo. Você terá garantido o direito à indenização compensatória caso fique comprovado que a sua participação acarretou algum problema a você.

Concordando em participar, você entende que este estudo será realizado em benefício das ciências médica e odontológica, e desta forma concorda com a divulgação dos dados obtidos por meio de publicações científicas. Esse termo de consentimento livre e esclarecido constará de duas vias, uma permanecerá com o pesquisador e outra será entregue a você.

Al. Dr. Octávio Pinheiro Brisolla, 9-75 - Bauru-SP - CEP 17012-901 - C.P. 73 e-mail: bioquimica@fob.usp.br- Fone/FAX (0xx14) 3235-8226/32234679 http://www.fob.usp.br 


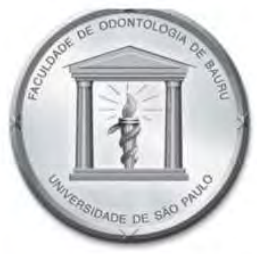

\section{Universidade de São Paulo Faculdade de Odontologia de Bauru}

Departamento de Ciências Biológicas

Disciplina de Bioquímica

Caso queira apresentar reclamações em relação à sua participação na pesquisa, poderá entrar em contato com o Comitê de Ética em Pesquisa em Seres Humanos da FOB-USP, no endereço Al. Octávio Pinheiro Brisolla, 9 75 (sala no prédio da Biblioteca, FOB-USP) ou pelo telefone (14) 3235-8356. Para maiores esclarecimentos de duvidas soube a pesquisa você pode, a qualquer momento, contatar a pesquisadora (Even Akemi Taira) pelos telefones (14)3010-6317, (14) 98141-1707 ou pelo e-mail: even.taira@usp.br

Fica claro que o voluntário poderá, a qualquer momento, retirar seu CONSENTIMENTO LIVRE E ESCLARECIDO e deixar de participar do estudo alvo da pesquisa e ciente que todo trabalho realizado torna-se informação confidencial guardada por força do sigilo profissional (Art. 9odo Código de Ética Odontológica).

Pelo presente instrumento que atende às exigências legais, o Sr. (a)

portador da cédula de identidade _ após leitura minuciosa das informações constantes neste TERMO DE CONSENTIMENTO LIVRE E ESCLARECIDO, devidamente explicada pelos profissionais em seus mínimos detalhes, ciente dos serviços e procedimentos aos quais será submetido, não restando quaisquer dúvidas a respeito do lido e explicado, DECLARA e FIRMA seu CONSENTIMENTO LIVRE E ESCLARECIDO concordando em participar da pesquisa proposta. Fica claro que o sujeito da pesquisa, pode a qualquer momento retirar seu CONSENTIMENTO LIVRE E ESCLARECIDO e deixar de participar desta pesquisa e ciente de que todas as informações prestadas tornar-se-ão confidenciais e guardadas por força de sigilo profissional (Art. $9^{\circ}$ do Código de Ética Odontológica). Por fim, como pesquisador(a) responsável pela pesquisa, DECLARO o cumprimento do disposto na Resolução CNS $n^{\circ} 466$ de 2012, contidos nos itens IV.3 e IV.4, este último se pertinente, item IV.5.a e na íntegra com a resolução CNS n 466 de dezembro de 2012.

Por estarmos de acordo com o presente termo o firmamos em duas vias igualmente válidas (uma via para o sujeito da pesquisa e outra para o pesquisador) que serão rubricadas em todas as suas páginas e assinadas ao seu término, conforme o disposto pela Resolução CNS nº 466 de 2012, itens IV.3.f e IV.5.d.

Bauru, SP de de

O Comitê de Ética em Pesquisa - CEP, organizado e criado pela FOB-USP, em 29/06/98 (Portaria GD/0698/FOB), previsto no item VII da Resolução n $466 / 12$ do Conselho Nacional de Saúde do Ministério da Saúde (publicada no DOU de 13/06/2013), é um Colegiado interdisciplinar e independente, de relevância pública, de caráter consultivo, deliberativo e educativo, criado para defender os interesses dos participantes da pesquisa em sua integridade e dignidade e para contribuir no desenvolvimento da pesquisa dentro de padrōes éticos.

Qualquer denúncia e/ou reclamação sobre sua participação na pesquisa poderá ser reportada a este CEP: Horário e local de funcionamento:

Comitê de Ética em Pesquisa

Faculdade de Odontologia de Bauru-USP - Prédio da Pós-Graduação (bloco E - pavimento superior), de segunda à sexta-feira, no horário das $13 \mathrm{~h} 30$ às 17 horas, em dias úteis.

Alameda Dr. Octávio Pinheiro Brisolla, 9-75 Vila Universitária - Bauru - SP - CEP 17012-901

Telefone/FAX(14)3235-8356 e-mail: cep@fob.usp.br

Al. Dr. Octávio Pinheiro Brisolla, 9-75 - Bauru-SP - CEP 17012-901 - C.P. 73 e-mail: bioquimica@fob.usp.br-Fone/FAX (0xx14) 3235-8226/32234679

http://www.fob.usp.br 